\title{
Working
}

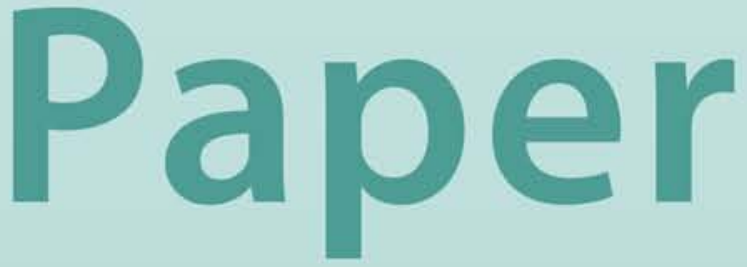




\section{Financial Reform: What Shakes It? What Shapes It?}

Abdul Abiad and Ashoka Mody 


\title{
IMF Working Paper
}

\author{
Research Department \\ Financial Reform: \\ What Shakes It? What Shapes It?
}

Prepared by Abdul Abiad and Ashoka Mody ${ }^{1}$

April 2003

\begin{abstract}
The views expressed in this Working Paper are those of the author(s) and do not necessarily represent those of the IMF or IMF policy. Working Papers describe research in progress by the author(s) and are published to elicit comments and to further debate.
\end{abstract}

Despite stops, gaps, and reversals, financial reforms advanced worldwide in the last quarter century. Using a new index of financial liberalization, we conclude that influential events shook the status quo, inducing both reforms and reversals, while learning, more so than ideology and country structure, shaped and sustained widespread reforms. Among shocks, a decline in global interest rates and balance of payments crises strengthened reformers; banking crises were associated with reversals, while new governments brought about both reforms and reversals. Learning occurred domestically-initial reforms raised the likelihood of further reforms - and through observing regional reform leaders. Among structural features, greater openness to trade appears to have increased the pace of financial reform.

JEL Classification Numbers:P11, P16, P34, N20, G28

Keywords: Financial reform; political economy; status quo bias

Authors’ E-Mail Addresses: aabiad@imf.org; amody@imf.org

\footnotetext{
${ }^{1}$ Research Department, International Monetary Fund. The authors are grateful for comments and suggestions to participants at the third Political Economy of International Finance Conference (Georgetown University, October 2002) and also to Eduardo Borensztein, Salim Darbar, Toni Gravelle, Russell Kincaid, Alex Mourmouras, Jacques Polak, Carmen Reinhart, Antonio Spilimbergo, Hung Tran, Liliana Schumacher, Michael Tomz, and David Walker.
} 


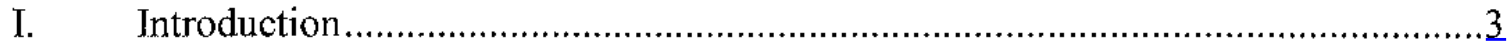

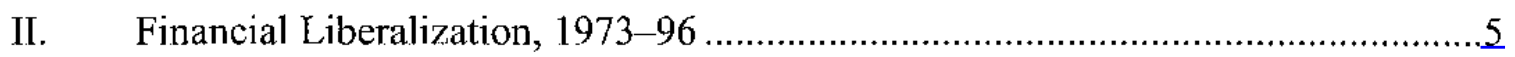

III. The Factors That Drive Reform: Literature Review ........................................10

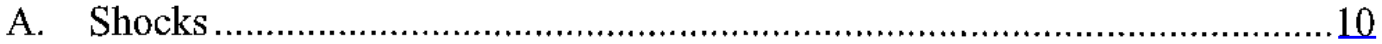

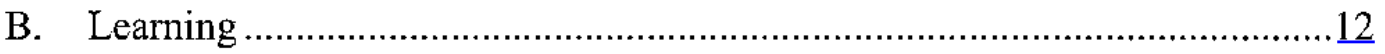

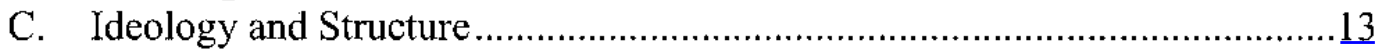

IV. Reform Determinants: Bivariate Relationships ..........................................14

V. Reform Determinants: Multivariate Analysis ............................................... 18

A. Benchmark Specification ................................................................19

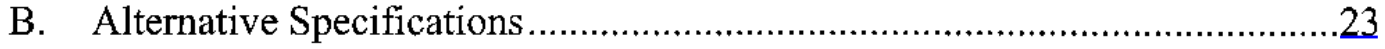

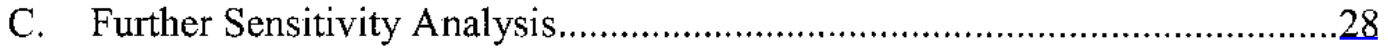

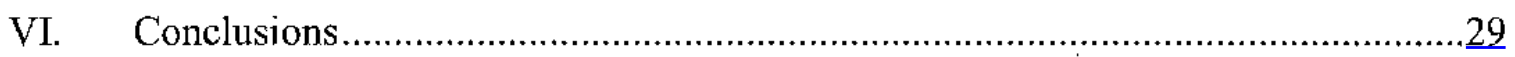

Text Tables

1. Correlations Among Financial Liberalization Components .................................

2. Distribution of Financial Policy Choices, Full Sample and by Region ..................

3. Policies, Political Conditions, and IMF Programs .........................................15

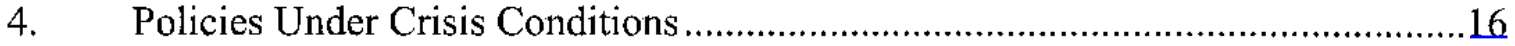

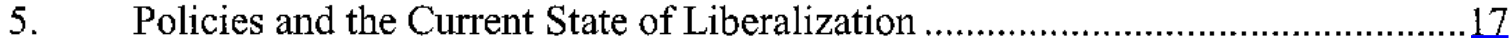

6. Policies, Ideology, and Structure .........................................................18

7. Ordered Logit Estimates: Benchmark Specifications (Equation 1) ....................22

8. Ordered Logit Estimates: Alternative Specifications (Equations 2 and 3) ..........25

9. Ordered Logit Estimates: Alternative Specification (Equation 4) .....................27

10. Goodness of Fit: Actual versus Predicted Policy .............................................28

\section{Figures}

1. Financial Liberalization by Income Group, 1973-96 …..................................

2. Financial Liberalization by Region, 1973-96............................................

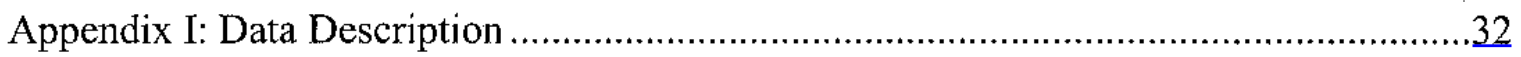

Appendix Table

A.1. The Financial Liberalization Index for 35 Countries, 1973-96.......................33

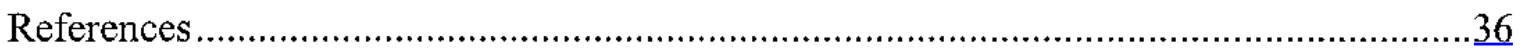




\section{INTRODUCTION}

In the last quarter of the twentieth century, financial sector reform was high on the agenda of policymakers. Though the trend worldwide was toward more liberalized financial systems, reform experiences differed considerably from one country to another, with their speed ranging from sluggish to swift and the magnitude of changes ranging from complete overhauls to minor tweaking. All countries experienced long stretches with no policy change and, occasionally, previous reforms were reversed. Our objective in this paper is to explain these variations. Using a newly constructed database, we document trends in financial sector reform and ask: when, by how much, and why did countries reform?

A large and technically sophisticated literature has examined the consequences of financial sector liberalization, but the causes of financial liberalization have received less attention. Levine (1997) summarizes the influence of financial development on growth. DemirgucKunt and Detragiache (1998) and Kaminsky and Reinhart (1999) discuss the causality from financial liberalization to economic crises. But what are the factors that stimulate financial sector reform? Do, for example, crises induce reforms? Country case studies have provided support for various economic and political theories of policy change. ${ }^{2}$ Case studies, however, have obvious limitations and, as Drazen (2000, p. 449) notes, "it is striking how little statistical testing there has been."3

A successful statistical examination of liberalization has to meet two challenges. First, policy changes tend to be episodic and the triggers for these episodes need to be identified. However, the episodes themselves-leading to both liberalizations and reversals-are embedded in a long-term process that, in the past quarter century, has trended toward greater liberalization. Thus, the second challenge is to identify a dynamic process that leads to these cumulative transformations.

We pursue a political economy perspective in explaining the timing, pace, and extent of financial sector reforms. The starting point of the analysis is an observed bias toward retaining the status quo, with the implication that established interest groups compromise to

\footnotetext{
${ }^{2}$ Individual country studies can be found in and Bates and Krueger (1993), Williamson (1994), Teichman (1997), and Edwards and Steiner (2000), among others.
}

${ }^{3}$ Bruno and Easterly (1996) and Drazen and Easterly (2001) test the crisis hypothesis by investigating whether periods of very high inflation have been followed by periods of substantially lower inflation (implying that reforms were implemented). Lora (1998) also investigates the role of crises in the timing and sequencing of reforms in a panel of Latin American countries. Other econometric investigations have either relied on proxies for reforms (e.g., financial development measures used by Rajan and Zingales, 2002) or have focused on only one aspect of financial liberalization (e.g., Quinn's 2000 study of the impact of democracy on capital account liberalization). 
maintain the existing policy regime. From the literature, we identify three sources of reforms. First, reforms may be triggered by discrete events, or "shocks," that change the balance of decision-making power. Of relevance are domestic events such as the "political honeymoon" following the formation of a new government, various types of crisis, and external influences, such as changes in global interest rates and leverage exercised by international financial institutions (Krueger, 1993). Second, "learning" may foster reform by revealing information that causes reassessment of the costs and benefits of the policy regime. Learning can also help resolve the impasse on account of uncertainty regarding the identity of winners (Fernandez and Rodrik, 1991). The term "learning" thus is shorthand for both discovery and the consequent realignments in relationships. ${ }^{4}$ Domestic learning may be supplemented by international "diffusion" as countries move to global or regional norms to compete for international capital (Simmons and Elkins, 2001). And, finally, reforms may be conditioned by political ideology of the ruling government (Alesina and Roubini, 1992; and Cukierman and Tommasi, 1998) and such structural features as openness to trade (Rajan and Zingales, 2002), legal system (La Porta and others, 1997), and form of government (Persson, 2002).

These sources of change-shocks, learning, and ideology and structure-have differing implications for the timing of liberalization. Following a shock, an immediate policy change may be undertaken. In contrast, learning allows for sustained changes. Where reforms are beneficial and/or alter the balance of power between competing interest groups, a learning process maintains a reform momentum, making further reforms more probable. Ideology and structure can act independently or can condition the response to events. This paper provides an integrated empirical framework to examine the various forces producing transitions to financial liberalization. The possibility of domestic learning implies a dynamic relationship between the level of financial sector liberalization and subsequent policy changes undertaken. The paper specifies such a relationship and, within that context, identifies the other factors that further strike at the status quo.

One constraint in analyzing the timing, direction, and size of policy changes has been the lack of a cross-country dataset on financial liberalization. Existing measures of liberalization refer either to a one-time change in rules (e.g., Bekaert and Harvey, 2000), which limits the investigation to episodes of liberalization, or to continuous proxies such as the level of financial development in an economy (e.g., Rajan and Zingales, 2002), which permit examination of long-term changes but not of discrete events. As the discussion above implies, liberalization is a mix of the episodic and the ongoing. Thus, an index is needed that combines both aspects of the reform-and reversal-process.

Our investigation uses a newly constructed financial liberalization index, covering 35 countries over the period 1973-96. The index allows a more precise determination of the timing and significance of various events cumulating in a financial liberalization process.

${ }^{4}$ In the context of trade policy reform, Krueger (1997) suggests that learning occured as a lagged adjustment to economic research that documented the benefits of reform. 
The index recognizes the multifaceted nature of financial reform and is an annual aggregation of financial reform along six dimensions. The six facets that characterize the financial sector policy are: directed credit/reserve requirements; interest rate controls; entry barriers and/or lack of pro-competition policies; restrictive operational regulations and/or lack of prudential regulations; the degree of privatization in the financial sector; and the degree of controls on international financial transactions. On each dimension, a country is classified as being fully repressed, partially repressed, largely liberalized, or fully liberalized.

To allow for the discrete nature of liberalization, we use the ordered logit technique to analyze the determinants of reform. Our results suggest that shocks mattered, learning was crucial, and ideology and structure appear to have played only a modest role in the financial reform process. What types of economic and political events shocked the status quo? Among external influences, reforms were promoted by a decline in U.S. interest rates and participation in programs of the International Monetary Fund (though this effect was pronounced mainly in countries where financial sectors were highly repressed). Crises were liable not only to induce reforms but also reversals. A balance of payments crisis typically triggered financial sector reforms, but banking crises were often associated with policy reversals. The tendency toward status quo weakened during a chief executive's first year in office, but changes included reversals as well as reforms. While these various events were influential, learning was essential to shaping and sustaining reforms. Countries with highly repressed financial sectors tended to stay that way but once initial reforms occurred, the process gained momentum and future reforms became more likely. Learning also occurred through observing regional reform leaders. Interestingly, ideology and structure seem to have had limited influence on the reform process. For example, left-wing governments were no less reform-oriented than right-wing governments, presidential and parliamentary regimes were equally inclined to reform, and legal systems did not come in the way of the move to liberalize. Greater trade openness, however, appears to have increased the pace of reform, especially where the level of liberalization was low.

The rest of the paper is organized as follows. In Section II, we describe the database of financial liberalization episodes and briefly highlight the salient features of financial reform over the past 25 years. Section III summarizes the relevant literature on the political economy of reform, focusing on the reasons for status quo bias and the conditions under which policy changes become more likely. In Section IV, we examine, one at a time, selected factors associated with policy changes. Section $V$ presents multivariate analysis and includes several extensions to test the robustness of the results. Section VI concludes.

\section{Financial Liberalization, 1973-96}

The new database used in this study considers various financial sector policies in 35 countries over the 24-year period from 1973 to 1996 . Six policy dimensions are inputs to the creation of an aggregate index of the degree of policy liberalization. These include:

- Credit controls, such as directed credit toward favored sectors or industries, ceilings on credit toward other sectors, and excessively high reserve requirements. 
- Interest rate controls, including whether the government directly controls interest rates, or whether floors, ceilings, or interest rate bands exist.

- Entry barriers, such as licensing requirements, limits on the participation of foreign banks, and restrictions relating to bank specialization or the establishment of universal banks.

- Regulations and securities markets; included here are operational restrictions, such as on staffing, branching and advertising, and the establishment of securities markets.

- Privatization in the financial sector.

- Restrictions on international financial transactions, such as on capital and current account convertibility, and the use of multiple exchange rates.

Along each dimension, a country is given a score on a graded scale, with zero corresponding to being fully repressed, one to partially repressed, two to largely liberalized, and three to fully liberalized. ${ }^{5}$ Policy changes, then, denote shifts in a country's score on this scale in a given year. In some cases, such as when all state-owned banks are privatized all at once, or when controls on all interest rates are simultaneously abolished, policy changes will correspond to jumps of more than one unit along that dimension. Reversals, such as the imposition of capital controls or interest rate controls, are recorded as shifts from a higher to a lower score. Given its detailed construction, the database thus allows a much more precise determination of the magnitude and timing of various events in the financial liberalization process.

Identifying the various policy changes included in our database was facilitated by the available surveys of financial liberalization experiences, such as Williamson and Mahar (1998), Fanelli and Medhora (1998), Johnston and Sundararajan (1999), De Brouwer and Pupphavesa (1999), and Caprio and others (2001). Nevertheless, frequent use of other resources, such as central bank bulletins and websites, IMF country reports, books, and journal articles was made when information was unclear or incomplete; references for each country are identified in the database itself.

Table 1 reports the correlations among the six components of financial liberalization. Some subcomponents show a higher correlation, indicating that the liberalizations along these

\footnotetext{
${ }^{5}$ Although the gradations are necessarily subjective, some guidelines were used to reduce the subjectivity. For example, interest rates were considered fully repressed where the government set all interest rates, partially repressed where interest rates were allowed to vary within a band or subject to a ceiling or floor, largely liberalized if some interest rates were allowed to be completely market-determined (or if new floating rate instruments were introduced), and fully liberalized where all interest rate restrictions were removed.
} 
dimensions tended to occur together. The three measures most frequently used as indicators of financial repression-credit controls, interest rate controls, and controls on international financial transactions - are all highly correlated with each other, with the correlations ranging from 0.76 to 0.82 . Less correlated are the measures of financial liberalization relating to cntry barriers and regulations. The measure of the extent of privatization in the financial sector has the lowest correlation with the other components, an indication that privatization docs not coincide with other reforms.

Table 1. Correlations Among Financial Liberalization Components

\begin{tabular}{|c|c|c|c|c|c|c|}
\hline & $\begin{array}{l}\text { Credit } \\
\text { Controls } \\
\end{array}$ & $\begin{array}{c}\text { Interest Rate } \\
\text { Controls }\end{array}$ & $\begin{array}{c}\text { Entry } \\
\text { Barriers }\end{array}$ & Regulations & Privatization & $\begin{array}{l}\text { International } \\
\text { 'Iransactions }\end{array}$ \\
\hline Credit controls & 1.00 & & & & & \\
\hline Interest rate controls & 0.82 & 1.00 & & & & \\
\hline Entry barriers & 0.65 & 0.66 & 1.00 & & & \\
\hline Regulations & 0.69 & 0.68 & 0.58 & 1.00 & & \\
\hline Privatization & 0.59 & 0.51 & 0.38 & 0.61 & 1.00 & \\
\hline International Transactions & 0.77 & 0.76 & 0.59 & 0.74 & 0.59 & 1.00 \\
\hline
\end{tabular}

The measures along the six dimensions can be aggregated to obtain an index of overall financial liberalization for each country in each year. Various aggregation methods produced very similar measures, so in this paper we simply use the sum of the individual components. ${ }^{6}$ Since each of the six indices can take on values between 0 and 3 , the sum takes on values between 0 and 18 . These aggregate measures of financial liberalization are tabulated for each country in the Data Appendix.

We draw four broad conclusions on the time profile of liberalization. First, despite stops, gaps, and reversals, financial scctor liberalization advanced through much of the world in the last quarter century (Figure 1). Countries in all income groups libcralized, though higherincome economies remained more liberalized than lower-income economies throughout.

\footnotetext{
${ }^{6}$ Four aggregation methods were explored: a simple sum, the first principal component, the sum of squares (which overweights large changes in a single component, so that major reforms in one dimension are deemed to be more significant than minor progress in many), and the sum of square roots (minor progress along many dimensions is deemed to be more effective than major progress in just one). All four aggregation methods produced overall measures that were highly comparable -correlations among the various series were mostly above 95 percent, and none was below 90 percent.
} 
Figure 1. Financial Liberalization by Income Group, 1973-1996

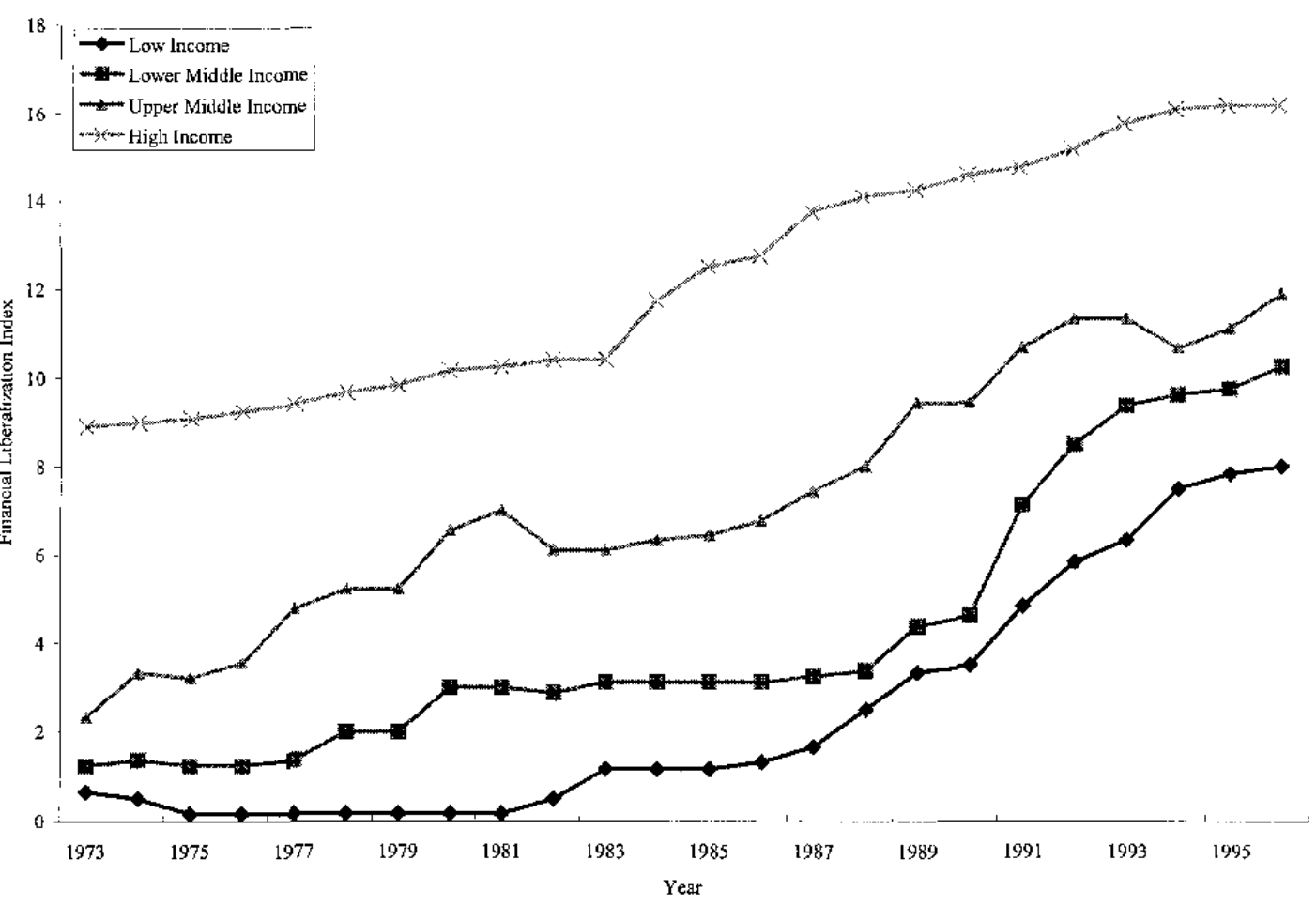

Figure 2. Financial Liberalization by Region, 1973-1996

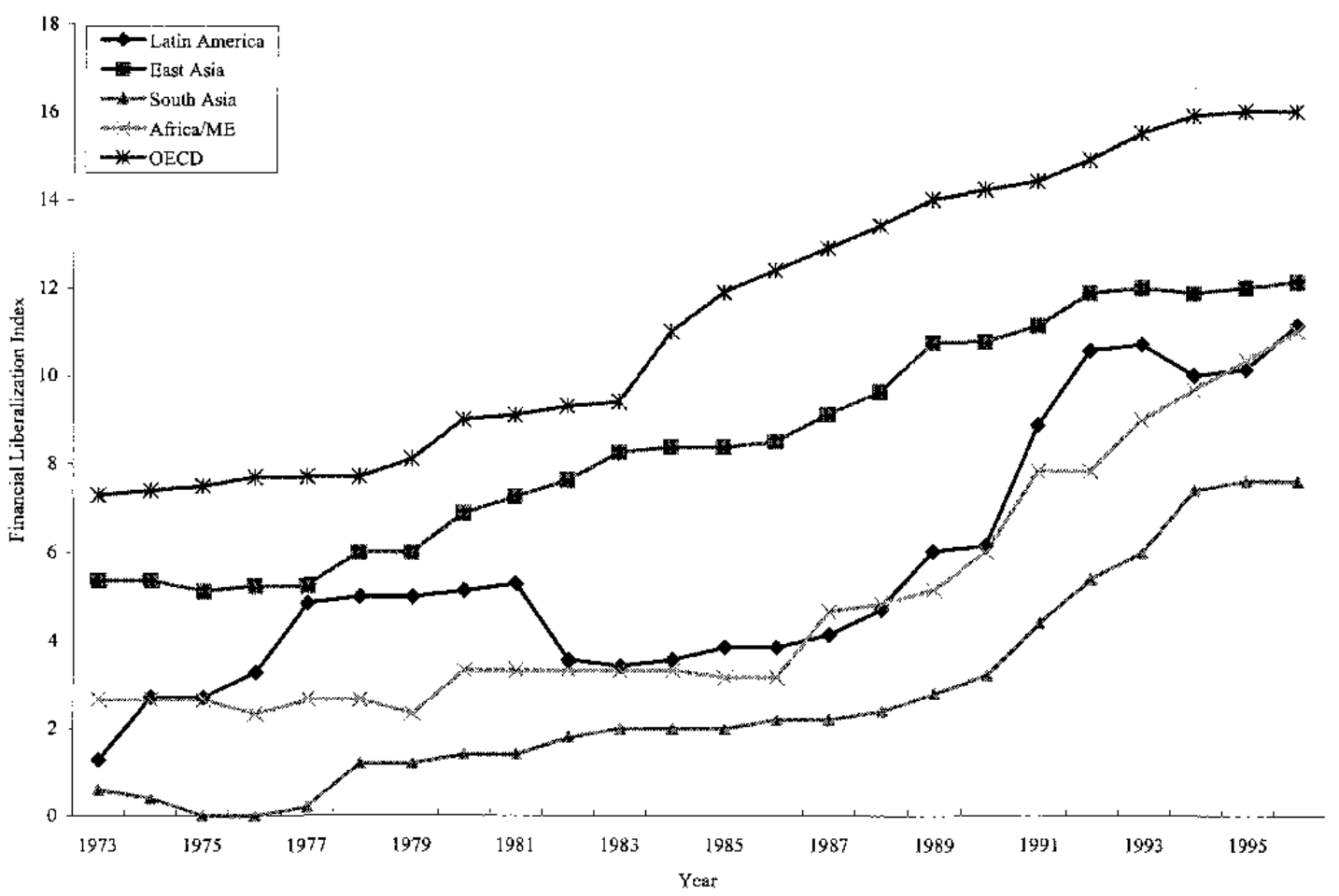


Second, while trends appear smooth in these country averages, the reform process at the country level was typically characterized by long periods of status quo, or no change in policy. To facilitate the exposition, we classify policy changes for each country-year into five categories. A decrease in the financial liberalization measure by 3 or more points is classified as a large reversal; a decrease of 1 or 2 points as a reversal; an increase by 1 or 2 points as a reform; and an increase of 3 or more points is classified as a large reform. Finally, years in which no policy changes were undertaken are classified as status quo observations. Table 2 shows the distribution of various policy changes in the whole sample, as well as by region. Status quo observations represent the large majority of observations-over 76 percent of the whole sample. Reforms constitute another 15 percent of the sample, and large reforms account for another 5 percent. Reversals are relatively rare and large reversals even more so. There were two large reversals in the sample, and both occurred in Latin America-in Argentina in 1982 and in Venezuela in 1994.

Table 2. Distribution of Financial Policy Choices, Full Sample and by Region (In percent)

\begin{tabular}{|c|c|c|c|c|c|c|}
\hline & $\begin{array}{c}\text { Full } \\
\text { Sample }\end{array}$ & $\begin{array}{c}\text { Latin } \\
\text { America }\end{array}$ & $\begin{array}{l}\text { East } \\
\text { Asia }\end{array}$ & $\begin{array}{r}\text { South } \\
\text { Asia } \\
\end{array}$ & $\begin{array}{c}\text { Africa/ } \\
\text { Middle East }\end{array}$ & OECD \\
\hline Large reform & 5.1 & 6.2 & 7.5 & 3.5 & 4.3 & 3.9 \\
\hline Reform & 15.4 & 11.2 & 14.3 & 17.4 & 13.8 & 19.1 \\
\hline Status quo & 76.2 & 78.3 & 73.9 & 75.7 & 79.7 & 74.3 \\
\hline Reversal & 3.1 & 3.1 & 4.3 & 3.5 & 2.2 & 2.6 \\
\hline Large reversal & 0.3 & 1.2 & 0.0 & 0.0 & 0.0 & 0.0 \\
\hline Total & 100.0 & 100.0 & 100.0 & 100.0 & 100.0 & 100.0 \\
\hline
\end{tabular}

Third, there is evidence of regional clustering: countries within certain regions have tended to liberalize their financial sectors at roughly the same time, and in roughly the same way. ${ }^{7}$ With the exception of early reforms in Argentina and Chile in the 1970s, most of the reforms in Latin America were clustered in the late 1980s and early 1990s (Figure 2). The two exceptions, Chile and Argentina, also illustrate that reform is not a steady march forward: both countries reversed policy during the debt crisis of 1982-83. The process of financial liberalization in East Asia was much more gradual. Countries opened up their financial sectors in small steps in the early 1980s, with the whole reform process stretching over a decade in most cases. South Asian financial sectors remain at least partially repressed even at the end of our sample period. South Asia's reforms occurred in the early to mid-1990s, with the exception of Sri Lanka, which undertook a major reform effort in 1978.

\footnotetext{
${ }^{7}$ Two OECD member countries, Korea and Mexico, are included in their regional grouping rather than in the OECD group. The income categories are based on the grouping in the World Bank's 2001 World Development Indicators.
} 
Finally, four of the OECD countries (Germany, Canada, the United Kingdom, and the United States) already had liberalized financial sectors at the beginning of our sample period. The rest of the OECD countries in our sample started the period with relatively repressed financial systems but caught up and now have largely or fully liberalized financial sectors via a gradual process beginning in the late 1970s and early 1980s. Only New Zcaland adopted a one-shot approach, undertaking most of its financial reforms in 1984-85.

\section{Tile FaCtors That Drive Reform: Literature ReVIEW}

The starting point for our analysis is that the status quo will persist so long as the benefits of maintaining it outweigh the costs for those who determine the timing and pace of policies. Theories of economic reforms fall into three broad categories: (a) "shocks" alter the balance of decision-making power, leading to both reforms and rcversals; (b) perceived payoffs are updated via discovery or a reduction in uncertainty, which we simply call "learning"; and (c) ideology and political and economic structure condition the pace of reform. We discuss each possibility in turn. In undertaking this literature review, we draw on the broader literature on the political economy of reform rather than merely on studies focused on financial liberalization. While a variety of theories suggest different determinants of economic reform, the empirical conclusions from the case studies and the limited number of econometric analyses are ambiguous. The empirical ambiguity reflects the multifaceted nature of reform, the difficulty in identifying the occurrence and timing of reforms, and the difficulty also in defining determining events such as crises.

\section{A. Shocks}

"Shocks" describe events that occur only cpisodically but trigger an almost immediate realignment of decision-making forces. Reflecting case-study evidence, Krueger (1993, p.124) summarizes: "Most reforms seem to take place in one of two circumstances: Either a new government comes to power or a perceived economic crisis prompts action." Other shocks considered in the literature include changes in the global economy and reform conditionality by international financial institutions.

It is widely held that policy reforms are more likely to be undertaken early in the electoral cycle. Haggard and Webb (1993) and Williamson (1994) refer to this as the "honeymoon hypothesis": extensive reforms can be implemented immediately after a government takes office. $^{8}$ Incumbents who are concerned about re-election may reject reform if the costs of the

\footnotetext{
${ }^{8}$ This would also suggest that dictatorships (and other autocratic forms of government) could undertake reforms more easily, since there are no elections to worry about at all. Similarly, Harberger (1993) refers to "a handful of heroes," who pushed needed reforms driven by long-term vision and implemented by the force of their personalities. We do not pursue these ideas here.
} 
policy are realized in the short run while the benefits are realized only over the longer haul (i.e., after their term in power). The evidence is mixed. Haggard and Webb (1993, p. 148), while sympathetic to, and noting cases in favor of, the "honeymoon" or "new government" hypothesis, point out, "new democratic leaders in Argentina, Bolivia, and Brazil pursued more expansionist policies in their early days and delayed needed reform."

Drazen (2000) discusses at length the mechanisms through which crises may lead to reforms. Competing elites, comfortable with the status quo in good times, may be less inclined to cooperate with each other when conditions worsen. As an example, consider Tornell's (1998) "reform-from-within" model, applied to the context of financial reform. Although all incumbents may favor financial repression, particular groups benefit from different types of restrictions. Incumbent borrowers support debtor-friendly regulations, such as loan rate ceilings and directed credit. Lenders seek instead to maintain creditor-friendly provisions such as entry barriers and weak prudential regulations. ${ }^{9}$ Following a crisis, cooperation among different incumbent groups breaks down, creating the potential for reform.

The evidence suggests that reaction to crises varies considerably. Nelson (1990), who examines 13 case studies of reforms, suggests that crises must be differentiated by their speed, intensity, and sources. She notes (p. 326), for example, that Rodrigo Carazo of Costa Rica "delayed and wavered in the face of a startlingly sudden crisis; indeed, one reason for ineffective reactions was the speed of deterioration, which ran far ahead of data collection and analysis." Drazen and Easterly (2001) find that it takes a severe crisis (hyperinflation) for a reform effort to coalesce. Lora (1998) examines a wide variety of reforms and, while crises appear to play a role in certain types of reforms, he obtains generally inconclusive results.

Besides crises, which may be either internally or externally induced, the literature points to other sources of external influence leading to reforms. First, changes in the global economy can influence the balance of decision-making power. Persson (2002) examines whether oil price movements change the influence of political institutions on economic policy. In the context of this study, global interest rates are of particular interest. Bartolini and Drazen (1997) argue that the level of international interest rates has an important bearing on incentives to undertake reform. During periods of low global rates ("good" times), international capital can be accessed cheaply. Hence, reformers are strengthened, and the likelihood of liberalizing increases. In contrast, when rates are high, the incentive to reform declines. $^{10}$

${ }^{9}$ A third interest group that may play a significant role is the public financial sector (stateowned banks). These may side with incumbent borrowers on some issues (directed credit), and with incumbent lenders on others (loan rate ceilings, few prudential regulations).

${ }^{10}$ Except for those countries, Bartolini and Drazen (1997) argue, which desire to signal their commitment to liberalization (and hence attract future investment) by maintaining their openness even in the face of high world interest rates. 
Second, international financial institutions may be able to induce reform. Through the conditionality they are able to impose, international financial institutions can act on behalf of domestic "outsiders," i.e., those who do not have an adequate voice in the political process. Outsiders include those excluded from access to credit and savers who receive low returns on their financial assets. For their benefit, an external impetus to reforms may originate as a condition of receipt of resources from international financial institutions. ${ }^{11}$ Haggard and Webb (1993) find, however, that the evidence is inconclusive with respect to the influence exercised by international financial institutions.

\section{B. Learning}

Fernandez and Rodrik (1991) explain the tendency to retain the status quo on the basis of uncertainty faced by individuals with respect to the outcomes following the reform (see also, Przeworski, 1991 and Labán and Sturzenegger 1994a and 1994b). ${ }^{12}$ If individuals or interest groups do not know ex ante who among them will benefit from reform, they may oppose the policy change even if it is socially optimal and a majority will benefit ex post. ${ }^{13}$ In the context of financial reform, even if some of the existing financial institutions may prosper post-liberalization, uncertainty regarding the identities of the winners and losers may cause the sector as a whole to oppose the reform.

Fernandez and Rodrik (1991) do not discuss mechanisms for discovery and, hence, why the status quo is eventually abandoned and reforms undertaken. Learning, made possible by the accumulation of new information, is particularly relevant in this context. If reform is a multistage process, then early reform may help agents assess whether they will benefit or lose

${ }^{11}$ In addition, Haggard and Webb (1994) note that external advisers from multilateral institutions, universities, and think tanks, as well as nationals previously associated with such organizations played a significant role in several reform episodes.

${ }^{12}$ Note that aside from the specifics of the Fernandez-Rodrik model, uncertainty has the general effect of dampening actions - and this is even more the case when ambiguity prevails (Erbas 2002), which arises when the probabilities of outcomes and the payoffs are imprecise, as distinct from uncertainty where the probabilities and payoffs are known.

${ }^{13}$ Fernandez and Rodrik (1991) provide an illustrative example. Assume that the losing sector L employs 60 percent of the population, and the benefiting sector $\mathrm{W}$ employs the other 40 percent. Now let reform lead to (i) a loss of -0.2 to those in $L$, (ii) a gain of 0.2 to those in $\mathrm{W}$, and (iii) a shift of one-third of the $\mathrm{L}$ workers to the $\mathrm{W}$ sector. The policy is socially optimal (the net gain is 0.04 ), and a majority (60 percent) will benefit ex post, but since individuals in the $\mathrm{L}$ sector do not know ex ante who among them will benefit, their expected return is -0.067 and they all vote down the reform. 
from reform. Incumbents who initially oppose reforms sometimes become the strongest advocates for further reforms.

To our knowledge, there is no systematic case study or econometric examination of the cascading effects of domestic reforms. However, Krueger (1993, p. 127) notes that following an initially successful reform program,

"strong political interests opposed to reform are to a considerable extent neutralized. If additional policy measures (and good luck) then provide additional economic gains, support for the reforms may strengthen and opponents are weakened. New interests emerge favoring the altered economic policies."

Learning may also occur---and reforms may cascade-when technical or managerial expertise in undertaking reforms is lacking. Under these conditions, implementation of multistage reform programs may need to be protracted. As expertise is gained from initial reforms, further reforms are more easily carried out.

Beyond the evolution of the domestic reform process, learning may also have external sources. Recent contributions to the political economy of reform - and to the spread of democracy — have noted a spatial clustering of activity and have, therefore, postulated a regional diffusion effect (for recent reviews, see Brinks and Coppedge, 2001; and Simmons and Elkins, 2001). The theories underlying regional diffusion are as yet speculative but they rely essentially on economic, social, and political similarities of neighboring nations and hence the relevance of their experience in informing domestic policy debates (O'Loughlin and others, 1998; Axelrod, 1997). Simmons and Elkins (2001), who find strong evidence for regional effects, conclude that countries within a region compete for the same international pool of risk capital.

\section{Ideology and Structure}

Finally, reforms may be conditioned by broader considerations of ideology and economic and political structure. These considerations may include the political orientation of the ruling parties, the forms of government (presidential versus parliamentary) and electoral rules, legal systems and creditor rights, and the country's degree of openness to international capital and trade.

With respect to ideology, the conventional view is that right-wing governments are more receptive to market-oriented reforms such as financial liberalization (for a discussion of partisan versus opportunistic politicians, see, for example, Alesina and Roubini, 1992). However, an opposing view arises if politicians cannot credibly convey the merits of their reform proposals. In such a situation, party ideology and credibility interact in interesting ways. Since the electorate cannot easily distinguish if a policy proposal is motivated by partisan considerations or by concerns for social welfare, a right-wing policy proposed by a left-wing government is vested with more credibility, being more likely to be motivated by social concerns. This, Cukierman and Tommasi (1998) argue, is especially true when rare 
and large reforms are being proposed. Thus, policy reforms become more credible when undertaken by political parties normally associated with ideologies opposed to those reforms.

Several political and economic structural factors have been proposed as conducive to reform. Persson (2002) argues that the presidential form of government is less prone than parliamentary systems to the logjam arising from conflicting interests. He similarly argues that certain electoral rules are more conducive to smaller governments. La Porta and others (1997) emphasize the importance of legal systems, as do Levine, Loayza, and Beck (2000). Rajan and Zingales (2002) suggest that in economies that are more open to international trade and investment, "insider" opposition to liberalization is weaker, as there is more to gain from the available new opportunities. In addition, they note that when "outsiders" such as foreign banks gain an initial foothold, they have a continuing incentive to push for further financial liberalization. They find more rapid financial sector development (as distinct from policy liberalization) when countries are more open to international trade and global capital flows are high.

While ideology and structure can have long-term influences on the direction and trajectory of reform, the question of interest is whether these overarching forces shaped the observed dynamics of financial sector reform in the last quarter of the twentieth century. Was the period long enough? Or, underlying the apparent differences, did a common ideology and the push of "globalization" apply everywhere? In our empirical analysis we include some of these considerations to assess their bearing on the pace of financial reform.

\section{REFORM DETERMINANTS: BIVARIATE RELATIONSHIPS}

In this section, we present selected bivariate relationships between policy changes and the conditions suggested by the theoretical and empirical literature reviewed above. These relationships have the benefit of greater transparency than the multivariate findings in Section V which corroborate these findings. Both in this section and the next, we focus on explaining movements in our aggregate index, rather than in the components. As noted above, the components are highly correlated. However, timing variations in the changes of particular components are of some interest and we discuss these in the sensitivity analysis.

Consider first the shocks that dislodge the status quo. The likelihood of reform, especially large reforms, increases significantly during an incumbent's first year in office (Table 3 , upper left-hand panel). ${ }^{14}$ The proportion of status quo observations drops from 78 percent to 70 percent. A Pearson chi-square test ${ }^{15}$ rejects the null hypothesis that the rows and columns

${ }^{14}$ See the Data Appendix for definitions of the independent variables used in this paper.

${ }^{15}$ The standard Pearson chi-square test statistic may be inaccurate if some of the cell frequencies are small. Yates' correction is an adjustment to the chi-square when applied to tables with one or more cells with frequencies less than five. This correction, also referred to as continuity correction, is conservative in the sense of making it more difficult to establish 
are independent. Change, then is more likely during the first year in office, supporting the opportunistic politician theory and the importance of the electoral cycle. Note, however, that the effect is not unidirectional; reversals are also more frequent during the first year in office, as noted by Haggard and Webb (1993). Next, we follow Tornell (1998) and derive an index of drastic political change from the Polity IV dataset of Marshall and Jaggers (2000). The drastic political change measure is intended to capture periods involving substantial changes in the form of government such as coups d'etat and the imposition or lifting of martial law. The upper right-hand panel of Table 3 shows that the likelihood of financial reform is unaffected by drastic political change. In fact, there is a slight increase in the relative frequency of status quo observations, which suggests that financial reform is probably not high on the agenda during such periods.

The reform orientation of the government may also change under external conditionality as, for example, if under a program with the IMF. The lower left-hand panel of Table 3 shows that while the chi-square statistic is not significant, IMF programs have a positive reform bias: the presence of an IMF program is associated with a greater likelihood of reform and a smaller likelihood of reversal.

Table 3. Policies, Political Conditions and IMF Programs

(In percent)

\begin{tabular}{|c|c|c|c|c|c|}
\hline & \multicolumn{2}{|c|}{ First Year in Office? } & & \multicolumn{2}{|c|}{ Drastic Poljtical Change? } \\
\hline & No & Yes & & No & Yes \\
\hline Large reform & 3.9 & 9.8 & Large reform & 5.2 & 3.9 \\
\hline Reform & 15.4 & 15.3 & Reform & 15.4 & 15.4 \\
\hline Status quo & 77.7 & 69.9 & Status quo & 76.0 & 78.9 \\
\hline Reversal & 3.0 & 3.7 & Reversal & 3.2 & 1.9 \\
\hline Large reversal & 0.0 & 1.2 & Large reversal & 0.3 & 0.0 \\
\hline Total & 100.0 & 100.0 & Total & 100.0 & 100.0 \\
\hline Pearson Chi-sq: & 12.52 & & Pearson Chi-sq: & 0.04 & \\
\hline Prob: & 0.01 & & Prob: & 1.00 & \\
\hline & \multicolumn{2}{|c|}{ IMF Program? } & & & \\
\hline & No & Yes & & & \\
\hline Large reform & 4.6 & $\overline{6.6}$ & & & \\
\hline Reform & 14.4 & 18.3 & & & \\
\hline Status quo & 77.2 & 73.2 & & & \\
\hline Reversal & 3.6 & 1.9 & & & \\
\hline Large reversal & 0.3 & 0.0 & & & \\
\hline Total & 100.0 & 100.0 & & & \\
\hline Pearson Chi-sq: & 3.42 & & & & \\
\hline $\begin{array}{r}\text { Prob: } \\
\end{array}$ & 0.49 & & & & \\
\hline
\end{tabular}

significance. Throughout this paper, we use this more conservative, continuity-corrected Pearson chi-square test statistic. 
Table 4 relates financial reform to different types of crises. A distinction is madc between balance of payments and banking crises, dates for which were compiled from the crisis database constructed by Bordo and others (2001). Other forms of adverse economic conditions considered include a recession, defined simply as negative GDP growth, and high inflation, defined as an annual inflation rate exceeding 50 percent. Under all four types of adversity, the relative frequency of status quo observations falls. However, the extent, and even the direction, of the policy change varies with the nature of the adversity. In response to a balance of payments crisis, the likelihood of a large reform increases from 3.1 percent to 9.7 percent. In contrast, when a country is in a banking crisis, the likelihood of a large financial reform falls from 5.5 percent to 2.6 percent and the possibility of reversals (big or small) increases from 2.3 percent to 9.5 percent. Finally, recessions and high inflation periods increase the likelihood of both reforms and reversals. For all four types of adversity, Pearson chi-square tests reject the null hypothesis that the distribution of policy changes is independent of the occurrence of a crisis, at the 1 percent level for balance of payments and banking crises, at the 5 percent level for high inflation cases, and at the 10 percent level for recessions.

Table 4. Policies Under Crisis Conditions

(In percent)

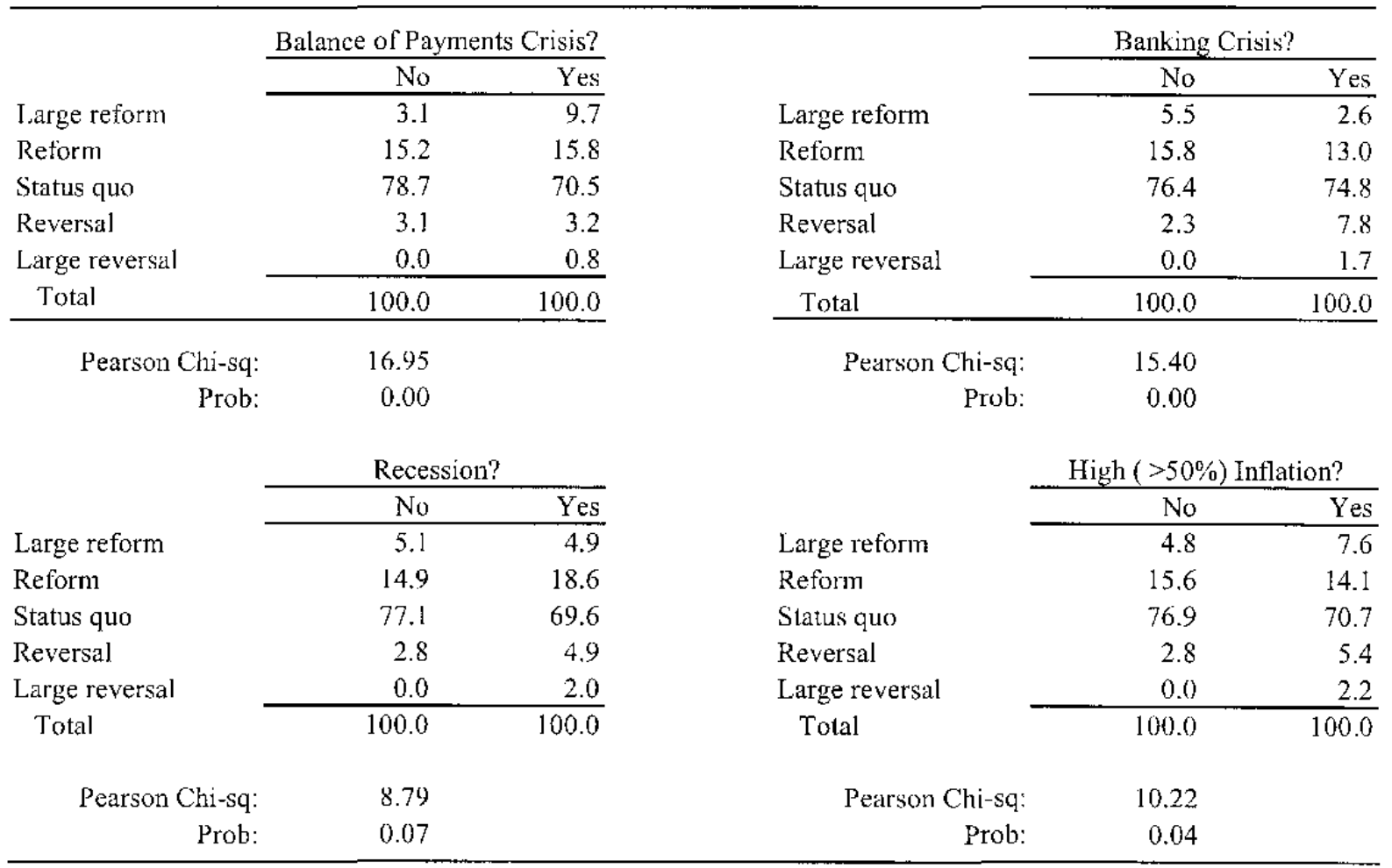

To assess the relevance of the learning process, we ask if the distribution of policy changes varies with the level of financial liberalization in a country. One might surmise a negative relationship, since countries with highly repressed financial sectors have the most potential 
for liberalizing, while liberalized economies have less left to do. Table 5, which tabulates policy changes under different levels of financial liberalization, shows that this is not quite the case. Instead, we find an inverse U-shaped curve. Countries with highly repressed financial systems tend to stay that way, as evidenced by the much higher proportion of status quo observations. But if these countries liberalize somewhat and become only partially repressed, then the likelihood of further reforms increases substantially. Reforms are much more probable in countries whose financial sectors are in an intermediate range of liberalization - either partially repressed or largely liberalized. Finally, when financial sectors are liberalized (the fourth column), reforms again become less likely. It is interesting to note that, in this sample at least, the liberalized state seems to be an absorbing state; none of the countries that reach the liberalized state undertook reversals of previous reforms.

The inverse U-shaped relationship between the level of financial liberalization and the incidence of reform supports the idea that "learning" creates a self-sustaining dynamic in the reform process. It also has an important implication for would-be reformers. Reforms do not have to be undertaken all at once-even small reforms are a victory, as they carry with them the seeds of future reforms.

Table 5. Policies and the Current State of Liberalization

(In percent)

\begin{tabular}{lrrrr}
\hline & \multicolumn{4}{c}{ Current State of Liberalization } \\
\cline { 2 - 5 } & \multicolumn{1}{c}{$\begin{array}{c}\text { Fully } \\
\text { Repressed }\end{array}$} & $\begin{array}{c}\text { Partially } \\
\text { Repressed }\end{array}$ & $\begin{array}{c}\text { Largely } \\
\text { Liberalized }\end{array}$ & Liberalized \\
\hline Large reform & 5.3 & 7.9 & 4.6 & 0.0 \\
Reform & 8.0 & 21.9 & 22.4 & 8.7 \\
Stalus quo & 85.9 & 64.1 & 67.2 & 91.3 \\
Reversal & 0.8 & 5.8 & 5.2 & 0.0 \\
Large reversal & 0.0 & 0.4 & 100.0 & 0.0 \\
$\quad$ Total & 100.0 & 100.0 & & 0.0 \\
& & & & \\
& & 58.54 & & 0.00 \\
\hline
\end{tabular}

Finally, we consider the role of ideology and political structure on policy reform. The upper left-hand panel of Table 6 shows the distribution of policy choices with the political orientation of the incumbent executive. ${ }^{16}$ The Pearson chi-square test statistic is insignificant, and the table shows that left-wing governments are no less reform-oriented than right winggovernments. In fact, the former are slightly more likely to undertake large reforms, while the latter are slightly more likely to reverse previous reforms, which would tend to support the theoretical results of Cukierman and Tommasi (1998). Different regime types-

${ }^{16}$ The orientation measure is taken from the World Bank's (2001) Database of Political Institutions; the Data Appendix contains a description of their ideology measure. 
presidential versus parliamentary forms of government-also do not have a significant effect on financial policy choices, as can be seen in the upper right-hand panel of Table 6 . This contrasts with the strong findings of Persson (2002) regarding the influence of regime type on fiscal policy. Lastly, we look at whether countries which are more open to trade are more reform-oriented. We measure openness by the sum of imports and exports relative to GDP, and classify observations into quartiles. We find no significant relationship between openness and financial policy choice.

Table 6. Policies, Ideology and Structure

(In percent)

\begin{tabular}{|c|c|c|c|}
\hline & \multicolumn{3}{|c|}{ Political Orientation? } \\
\hline & Left & $\begin{array}{r}\text { Center/ } \\
\text { Other }\end{array}$ & Right \\
\hline Large reform & 6.6 & 5.0 & 4.4 \\
\hline Reform & 15.5 & 13.6 & 17.1 \\
\hline Status quo & 75.1 & 78.8 & 74.2 \\
\hline Reversal & 2.8 & 2.0 & 4.4 \\
\hline Large reversal & 0.0 & 0.7 & 0.0 \\
\hline Total & 100.0 & 100.0 & 100.0 \\
\hline Pearson Chi-sq: & 5.18 & & \\
\hline Prob: & 0.74 & & \\
\hline
\end{tabular}

System of Government?

\begin{tabular}{lrr}
\hline & & \\
& Presidential & Parliamentary \\
\hline Large reform & 0.0 & 0.5 \\
Reform & 3.2 & 3.0 \\
Status quo & 74.3 & 77.0 \\
Reversal & 16.8 & 14.7 \\
Large reversal & 5.6 & 4.8 \\
\cline { 2 - 3 } Total & 100.0 & 100.0 \\
\hline
\end{tabular}

Reform

Status quo

Reversal

Large reversal

Total

\begin{tabular}{rrrr}
\hline \multicolumn{4}{c}{ Trade Openness } \\
\hline First & Second & Third & Fourth \\
Quartile & Quartile & Quartile & Quartile \\
\hline 0.5 & 0.0 & 0.5 & 0.0 \\
3.5 & 3.4 & 1.5 & 4.0 \\
77.4 & 73.5 & 76.6 & 77.1 \\
15.6 & 16.2 & 16.9 & 12.9 \\
3.0 & 6.9 & 4.5 & 6.0 \\
\hline 100.0 & 100.0 & 100.0 & 100.0
\end{tabular}

Pearson Chi-sq:

Prob:

1.17

0.88

\section{REFORM DETERMINANTS: MULTIVARIATE ANALYSIS}

We investigate the robustness of the findings in the previous section by analyzing the various determinants of policy change in a multivariate context. Recall that our liberalization measure sums the six components of financial liberalization, each ranging from 0 to 3 and hence the overall measure takes on integer values between 0 and 18 . To facilitate interpretation of the regressions, we divide the overall liberalization measure by 18 to get an index, $F L_{i t}$, which ranges from 0 to 1 , with 0 corresponding to a completely repressed financial sector and 1 corresponding to a fully liberalized financial sector. Our dependent 
variable is $\triangle F L_{i t}$, which measures policy changes. Given the discrete, ordinal nature of the dependent variable, we use the ordered logit method for our estimation. ${ }^{17}$

\section{A. Benchmark Specification}

As discussed in Section III, the status quo may be altered by shocks or events that alter the power balance among competing groups, domestic and regional learning processes, or ideological or structural factors. To model the domestic "learning" process, we specify a simple reduced-form dynamic process. Policy change is affected by the difference between the desired level of financial liberalization, $F L_{i t}^{*}$, and the current level of financial liberalization, $F L_{i, l-1}$, so that

$$
\Delta F L_{i t}=\alpha\left(F L_{i t}^{*}-F L_{i, t-1}\right)+\varepsilon_{i t}
$$

The adjustment factor, $\alpha$, is a measure of the status quo bias: the lower $\alpha$ is, the greater the status quo bias. Since $F L_{i t}^{*}$, is not observable, we begin in our benchmark model with the assumption that the desired level of financial liberalization is $F L_{i t}^{*}=1$. This assumption implies that financial liberalization is regarded by policymakers as welfare-enhancing and that full liberalization represents a "global norm." Other possibilities, including countryspecific measures of desired liberalization, are explored in the next section. Second, the adjustment factor, $\alpha$, is likely to be time-varying, allowing for the possibility of learning. Following the theoretical literature, we assume that the resistance to reform is a function of the state of liberalization, i.e., $\alpha=k \cdot F L_{i, t-1}, k>0$. The assumption here is that status quo bias is highest when financial sectors are repressed and the bias declines as the sector is liberalized. Such a dynamic would occur, for example, in a multi-stage version of the Fernandez-Rodrik model where earlier reforms help identify winners and losers. It is also consistent with the need to build technical and managerial expertise in reform implementation and with a strengthening of "outside" groups" position relative to incumbents. We can thus rewrite equation above as:

$$
\Delta F L_{i t}=\theta_{1} F L_{i, t-1}\left(1-F L_{i, t-1}\right)+\varepsilon_{i t}
$$

Next, we allow for the possibility of regional diffusion. If such an influence was important, countries within a region would be induced to "catch up" with the highest level of liberalization reached within the region (the regional "norm"), either due to a reduction in uncertainty regarding the benefits of reform or due to competition for external capital flows.

${ }^{17}$ Estimation using ordered probit produces similar results. The degree of excess of our dependent variable $\Delta F L_{i t}$ is $22.8 / 1.48^{2}-3=7.4$, suggesting that the use of the (leptokurtic) logistic distribution is more appropriate. 
The higher the gap between the maximum level of liberalization achieved in the region ( $\left.R E G_{-} F L_{i, t-1}\right)$ and the level of a country's state of liberalization $\left(F L_{i, t-1}\right)$, the higher would be probability of further liberalization:

$$
\Delta F L_{i t}=\theta_{1} F L_{i, t-1}\left(1-F L_{i, t-1}\right)+\theta_{2}\left(R E G_{-} F L_{i, t-1}-F L_{i, t-1}\right)+\varepsilon_{i t}
$$

In addition, various shocks can dislodge the status quo and ideology and structure can influence the speed of reforms. We include in our empirical analyses a set of variables reflecting these influences (SHOCKS $i t, I D E O L O G Y_{i t}$, and $S T R U C T U R E_{i t}$ respectively). This implies the following specification:

$$
\begin{aligned}
\Delta F L_{i t} & =\theta_{1} F L_{i, t-1}\left(1-F L_{i, t-1}\right)+\theta_{2}\left(R E G_{-} F L_{i, t-1}-F L_{i, t-1}\right) \\
& +\theta_{3}{ }^{\prime} S H O C K S_{i t}+\theta_{4}^{\prime} I D E O L O G Y_{i t}+\theta_{5}{ }^{\prime} S T R U C T U R E_{i t}+\varepsilon_{i t}
\end{aligned}
$$

In the category of "shocks," we first consider different types of crises, or economic adversity. These include, as discussed in Section III: a balance of payments crisis dummy $\left(B O P_{i t}\right)$, a banking crisis dummy $\left(B A N K_{i t}\right)$, a recession dummy ( $\left.R E C E S S I O N_{i t}\right)$, and a high inflation dummy $\left(H I N F L_{i t}\right){ }^{18}$ For the political "shock" variables, we examine the "honeymoon hypothesis" by including a dummy variable indicating the incumbent executive's first year in office ( FIRSTYEAR $_{i t}$ ). The influence of IFIs on policy reform is proxied by an IMF program dummy $\left(I M F_{i t}\right)$. And to explore the influence of the global factors we include international interest rates $\left(U S I N T_{t}\right) .{ }^{19}$ To assess the effect of political orientation on reform, we include dummy variables for left-wing and right-wing governments $\left(L E F T_{i t}, R I G H T_{i t}\right)$; centrist governments are the omitted category. The only structural variable included here is trade openness $\left(O P E N_{i t}\right)$; in the sensitivity analysis below, we consider additional structural variables that may be relevant but are effectively time-invariant, such as legal origin and the system of government. In our discussion, we summarize also results obtained by interacting the ideology and structural variables with the "shock" variables, on the premise that ideology

\footnotetext{
${ }^{18}$ For banking and balance of payments crises, the dummy variable takes the value 1 if there was a crisis within the past two years. Of the 875 observations in our sample, 120 observations are associated with banking crises. Of these, 58 occur when there is no balance of payments crisis and 62 overlap with balance of payments crises. Similarly, the balance of payments crisis dummy takes the value 1 for 260 observations.

${ }^{19}$ The "drastic political change" variable $D P C_{i t}$ described in Section IV was also considered but, as in Table 3, it was found to be insignificant. As regards global factors, world oil prices were also considered in addition to world interest rates, but were found to be insignificant.
} 
and structure may indirectly influence the speed of response following shocks. Descriptions of the variables used can be found in the Data Appendix.

Results in Table 7 are presented without and with country fixed effects. Columns 1 and 4 show the result of regressing $\triangle F L_{i t}$ on the domestic learning dynamic, $F L_{i, t-1}\left(1-F L_{i, t-1}\right)$, and on the regional diffusion variable, $\left(R E G_{-} F L_{i, t \cdots 1}-F L_{i, t-1}\right)$. The coefficient on $F L_{i, t-1}\left(1-F L_{i, t-1}\right)$ is positive and significant at the 1 percent level, confirming the conjecturc that status quo bias decreases as financial liberalization increases, and verifying the inverse U-shaped relationship between policy change and the level of libcralization suggested in Table 5. The regional diffusion effect is additional to domestic learning and is also strongly significant, suggesting that regional leaders exercise a strong pull towards liberalization.

The crisis/adversity dummies are added to the regression in columns 2 and 5 . Consistent with Table 4 , the coefficient on the balance of payments crisis dummy variable is positive, suggesting that these crises are an impetus to reform, while the coefficient on the banking crisis dumny is negative, confirming the earlier finding that reforms are less likely following banking crises and reversals more likely. The effects of the recession and high inflation dummy variables are insignificant, possibly because, as Table 4 shows, both reforms and reversals become more likely.

In columns 3 and 6 "shock" variables are included. The coefficient on the dummy variable for the first year in office is positive but not significant. Recall, the bivariate analysis (Table 3) showed change in both directions during the first year in office. The positive but insignificant coefficient possibly results from the increased likelihood of reform being (partially) offset by the increased likelihood of reversals. The IMF program dummy has a positive coefficient, indicating movement towards reform during periods of IMF programs. It is marginally significant when country dummies are not included, but becomes insignificant when country dummies are added, suggesting that the factors that lead to an IMF program also hasten financial reform. In line with Bartolini and Drazen (1997), a rise in U.S. interest rates is seen to slow down the pace of financial sector liberalization. Not surprisingly, since US interest rates vary only over time and not across countries, their effect is seen to be stronger when the within-country variation is isolated in the fixed effects regression.

Finally, consider the ideology and structure variables that display some variation over time (other variables are considered in the sensitivity analysis). The coefficient on the left-wing dummy variable is larger than that on the right-wing dummy variable, suggesting that leftwing governments tend to reform more than right-wing governments. However, the results indicate no statistical difference across party ideologies - a somewhat less spectacular result that that proposed by Cukierman and Tommasi (1998), but impressive and important nevertheless. Lastly, a country's openness to trade, as measured by the sum of imports and exports relative to GDP, is not significant in these regressions. 
Table 7. Ordered Logit Estimates: Benchnark Specification (Equation 1)

\begin{tabular}{|c|c|c|c|c|c|c|}
\hline \multirow[b]{2}{*}{$F L_{i, t-1} \times\left(I-F L_{i, t-1}\right)$} & \multicolumn{3}{|c|}{ Without Country Fixed Effects } & \multicolumn{3}{|c|}{ With Country Fixed Effects } \\
\hline & $\begin{array}{l}4.001^{* * *} \\
(0.966)\end{array}$ & $\begin{array}{l}4^{4.167} \\
(0.991)\end{array}$ & $\begin{array}{l}4.188^{* * *} \\
(0.984)\end{array}$ & $\begin{array}{l}6.316^{* * *} \\
(1.512)\end{array}$ & $\begin{array}{l}6.388^{* * *} \\
(1.579)\end{array}$ & $\begin{array}{l}6.295 * * * \\
(1.577)\end{array}$ \\
\hline$R E G_{-} F L_{i, t,-1}-F L_{i, t-1}$ & $\begin{array}{l}0.842^{* * *} \\
(0.248)\end{array}$ & $\begin{array}{l}0.948^{* * *} \\
(0.301)\end{array}$ & $\begin{array}{l}0.993^{* * *} \\
(0.314)\end{array}$ & $\begin{array}{l}1.940^{* * *} \\
(0.695)\end{array}$ & $\begin{array}{l}2.319 \text { **** } \\
(0.834)\end{array}$ & $\begin{array}{l}2.324 * * * \\
(0.830)\end{array}$ \\
\hline$B O P_{i t}$ & & $\begin{array}{l}0.460 * * \\
(0.189)\end{array}$ & $\begin{array}{l}0.439 * * \\
(0.190)\end{array}$ & & $\begin{array}{c}0.471 * \\
(0.245)\end{array}$ & $\begin{array}{c}0.488^{* *} \\
(0.244)\end{array}$ \\
\hline$B A N K_{i t}$ & & $\begin{array}{l}-0.985 \text { *** } \\
(0.361)\end{array}$ & $\begin{array}{l}-0.993 * * * \\
(0.361)\end{array}$ & & $\begin{array}{l}-0.959 \text { *** } \\
(0.363)\end{array}$ & $\begin{array}{l}-0.965 * * * \\
(0.358)\end{array}$ \\
\hline RECESSION & & $\begin{array}{r}-0.059 \\
(0.345)\end{array}$ & $\begin{array}{r}-0.056 \\
(0.338)\end{array}$ & & $\begin{array}{r}-0.063 \\
(0.361)\end{array}$ & $\begin{array}{r}-0.059 \\
(0.366)\end{array}$ \\
\hline$H I N F L_{i t}$ & & $\begin{array}{r}-0.209 \\
(0.401)\end{array}$ & $\begin{array}{r}-0.264 \\
(0.399)\end{array}$ & & $\begin{array}{r}-0.353 \\
(0.643)\end{array}$ & $\begin{array}{r}-0.343 \\
(0.652)\end{array}$ \\
\hline$F_{I R S T Y E A R_{i t}}$ & & $\begin{array}{r}0.240 \\
(0.222)\end{array}$ & $\begin{array}{r}0.194 \\
(0.231)\end{array}$ & & $\begin{array}{r}0.242 \\
(0.262)\end{array}$ & $\begin{array}{r}0.242 \\
(0.270)\end{array}$ \\
\hline$I M F_{i t}$ & & $\begin{array}{r}0.295 \\
(0.185)\end{array}$ & $\begin{array}{c}0.326^{*} \\
(0.186)\end{array}$ & & $\begin{array}{r}0.348 \\
(0.269)\end{array}$ & $\begin{array}{r}0.324 \\
(0.261)\end{array}$ \\
\hline USINT, & & $\begin{array}{c}-0.070 * \\
(0.038)\end{array}$ & $\begin{array}{c}-0.066^{*} \\
(0.038)\end{array}$ & & $\begin{array}{l}-0.087^{* *} \\
(0.042)\end{array}$ & $\begin{array}{l}-0.089^{* *} \\
(0.044)\end{array}$ \\
\hline$L E F Y_{i t}$ & & & $\begin{array}{r}0.242 \\
(0.242)\end{array}$ & & & $\begin{array}{r}-0.072 \\
(0.366)\end{array}$ \\
\hline$R I G H T_{i t}$ & & & $\begin{array}{r}0.169 \\
(0.190)\end{array}$ & & & $\begin{array}{r}-0.196 \\
(0.338)\end{array}$ \\
\hline$O P E N_{i t}$ & & & $\begin{array}{r}-0.001 \\
(0.001)\end{array}$ & & & $\begin{array}{r}0.006 \\
(0.009)\end{array}$ \\
\hline $\log L$ & -762.662 & -748.17 & -747.20 & .749 .1 & -734.56 & -734.11 \\
\hline $\begin{array}{l}\text { Wald test of joint } \\
\text { significance ( } p \text {-value) } \\
\text { Number of observations }\end{array}$ & $\begin{array}{r}0.000 \\
805\end{array}$ & $\begin{array}{r}0.00 \\
805\end{array}$ & $\begin{array}{r}0.00 \\
805\end{array}$ & $\begin{array}{r}0.000 \\
805\end{array}$ & $\begin{array}{r}0.00 \\
805\end{array}$ & $\begin{array}{r}0.00 \\
805\end{array}$ \\
\hline
\end{tabular}

Note 1: The dependent variable is the change in the Financial Liberalization lndex, ?FL $i t$.

Note 2: Robust standard errors are in parentheses; adjusted for clustering by country. ${ }^{* * *}$ denotes significance at the 1 percent level; ${ }^{* *}$ denotes significance at the 5 percent level; ${ }^{*}$ denotes significance at the 10 percent levcl.

Interacting the ideology and structural variables with the "shock" variables did not produce any additional significant results. Coefficient estimates were more positive for left-wing governments during balance of payments crises, and more negative for right-wing governments during banking crises, but as in the uninteracted case, these differences were not significant. Also, Rajan and Zingales (2002) argue that it is the combination of trade openness and availability of foreign capital that makes incumbents more willing to liberalize the financial sector. To capture this idea we interacted of $O P E N_{i t}$ with $U S I N T_{t}$ (the latter proxying for the availability of foreign capital), but the results remained insignificant.

The coefficient estimates in Table 7 do not give the marginal effects of the right-hand side variables on the probabilities of reform, reversal, and status quo. Calculations (available from the authors) of these marginal effects on probabilities, evaluated at the means of the righthand side variable, show that a balance of payments crisis increases the likelihood of reform 
by 8 percentage points; a banking crisis lowers it by 12 percentage points. An IMF program increases reform likelihood by 5 percentage points. The effect of a one-unit change in $R E G_{-} F L_{i, t-1}$ (i.e., the "reform leadcr" going from fully repressed to fully liberalized) increases reform likelihood by 35 percentage points.

To sum up, status quo bias declines as the financial sector bccomes more liberalizedcountries with highly repressed financial sectors tend to stay that way, but once reforms are initiated, the likelihood of additional reforms increases. Regional diffusion effects are strong. The easing of U.S. interest rates appears to lower costs of financial reform. IMF programs seem to be associated with faster reform, but the results caution that this association may reflect unobserved country features. While balance of payments crises tend to increase the likelihood of financial reforms, banking crises tend to increase the likelihood of reversals. The first year in office is associated with policy changes in both directions. Left wing and right wing governments are seen to operate similarly in similar situations, and openness to trade docs not, on average, increase the pace of reform.

\section{B. Alternative Specifications}

Two important assumptions guided the benchmark empirical specification. We assumed that the desired level of financial liberalization is full liberalization. This may not be the case if, for example, institutional quality limits the prudent level of liberalization. We also assumed that the speed of adjustment to the desired level of liberalization is a function only of the current level of liberalization. Again, shocks of various kinds may induce policy reforms through changing the "adjustment" parameter. Here we examine the implications of relaxing both assumptions. The results reported above remain robust. However, interpretation is enhanced since the various interaction terms introduced in these more complex specifications suggest ranges of the state of financial liberalization where particular influences may be significant, even though they are not seen to be significant on average.

To allow for varying levels of "desircd" financial liberalization, we relax the assumption that the desired level of financial liberalization is full liberalization, i.e., that $F L_{i i}^{*}=1$ and explore two alternative specifications. The first alternative is that the desired level of liberalization is constant but not necessarily equal to 1 , so that $F L_{i t}^{*}=c$. Under this assumption, the coefficients on $F L_{i, t-1}$ and $F L_{i, t-1}^{2}$ are no longer constrained to be equal. Instead, when combined with Equation (1) and our earlier assumption that $\alpha=k \cdot F L_{i, t-1}$, we obtain the alternative specification

$$
\begin{aligned}
\Delta F L_{i t} & =\theta_{1} F L_{i, t-1}+\theta_{2} F L_{i, t-1}^{2}+\theta_{3}\left(R E G_{-} F L_{i, t-1}-F L_{i, t-1}\right) \\
& +\theta_{4}{ }^{\prime} S H O C K S_{i t}+\theta_{5}^{\prime} L D E O L O G Y_{i t}+\theta_{6}^{\prime} S_{T R U C T U R E_{i t}}+\varepsilon_{i t}
\end{aligned}
$$


where $\theta_{1}=k c$ is expected to be positive, and $\theta_{2}=-k$ is expected to be negative. Testing whether $\theta_{1}=-\theta_{2}$ would be equivalent to testing whether the assumption that $F L_{i t}^{*}=1$ is valid.

A second alternative is that the desired level of financial liberalization increases with a country's level of economic development. Less developed countries will tend to have poorer institutional quality that limits the capacity to undertake far-reaching reform; also, at lower levels of income, governments may perceive more opportunities to channel credit toward sectors that can generate positive externalities. This would suggest that $F L_{i t}^{*}=a+b Y_{i t}$, where $Y_{i t}$ is a measure of economic development, and would imply the following specification:

$$
\begin{aligned}
\Delta F L_{i t} & =\theta_{1} F L_{i, t-1}+\theta_{2} F L_{i, t-1}^{2}+\theta_{3}\left(F L_{i, t-1} \cdot Y_{i t}\right)+\theta_{4}\left(R E G_{-} F L_{i, t-1}-F L_{i, t-1}\right) \\
& +\theta_{5}{ }^{\prime} S H O C K S_{i t}+\theta_{6}{ }^{\prime} I D E O L O G Y_{i t}+\theta_{7}{ }^{\prime} S T R U C T U R E_{i t}+\varepsilon_{i t}
\end{aligned}
$$

where $\theta_{1}=k a$ and $\theta_{3}=k b$ are expected to be positive, and $\theta_{2}=-k$ is expected to be negative. The measure of the level of development used is GDP per capita in PPP terms from the Penn World Tables.

The estimation results for specifications (2) and (3) are reported in Table 8, again with and without fixed effects. The main results from the previous section are preserved in the alternative specifications, namely the inverse U-shaped relationship between $\triangle F L_{i t}$ and $F L_{i, t-1}$, the positive and negative effects of $B O P_{i t}$ and $B A N K_{i t}$, respectively, and the influence of world interest rates. The term representing the regional gap remains positive in all estimations and significant in two of them. Once again the IMF dummy is significant without country fixed effects but becomes insignificant when fixed effects are included. All other variables remain insignificant as before. 
Table 8. Ordered Logit Estimates: Altemative Specifications (Equations 2 and 3)

\begin{tabular}{|c|c|c|c|c|}
\hline \multirow[b]{2}{*}{$F l_{i, t-1}$} & \multicolumn{2}{|c|}{ Without Country Fixed Effects } & \multicolumn{2}{|c|}{ With Country Fixed Effects } \\
\hline & $\begin{array}{l}4.161 * * * \\
(0.974)\end{array}$ & $\begin{array}{l}4.314 * * * \\
(0.973)\end{array}$ & $\begin{array}{l}6.130 * * * \\
(1.532)\end{array}$ & $\begin{array}{l}6.662 * * * \\
(1.583)\end{array}$ \\
\hline$\left(F L_{i, t-i}\right)^{2}$ & $\begin{array}{l}-4.324 * * * \\
(1.053)\end{array}$ & $\begin{array}{l}-6.091 * * * \\
(1.382)\end{array}$ & $\begin{array}{l}-6.701 * * * \\
(2.043)\end{array}$ & $\begin{array}{l}-9.763 \text { *** } \\
(2.641)\end{array}$ \\
\hline$F L_{i, 1-1} \times Y_{j, 1-1}$ & & $\begin{array}{l}0.103 * * \\
(0.043)\end{array}$ & & $\begin{array}{c}0.234 \text { ** } \\
(0.097)\end{array}$ \\
\hline$R E G_{-} F L_{i, t-1}-F L_{i, t-1}$ & $\begin{array}{l}0.896 * * \\
(0.426)\end{array}$ & $\begin{array}{r}0.568 \\
(0.487)\end{array}$ & $\begin{array}{r}1.902 \\
(1.291)\end{array}$ & $\begin{array}{l}2.070 * \\
(1.242)\end{array}$ \\
\hline$B O P_{i}$ & $\begin{array}{l}0.440 * * \\
(0.190)\end{array}$ & $\begin{array}{l}0.489 * * \\
(0.193)\end{array}$ & $\begin{array}{l}0.4711^{* *} \\
(0.233)\end{array}$ & $\begin{array}{r}0.454 * \\
(0.233)\end{array}$ \\
\hline$B A N K_{i t}$ & $\begin{array}{l}-0.988^{* * * *} \\
(0.359)\end{array}$ & $\begin{array}{l}-0.980 * * * \\
(0.357)\end{array}$ & $\begin{array}{l}-0.942 * * * \\
(0.343)\end{array}$ & $\begin{array}{l}-1.014^{* * * *} \\
(0.344)\end{array}$ \\
\hline RECESSION $_{i t}$ & $\begin{array}{r}-0.043 \\
(0.334)\end{array}$ & $\begin{array}{r}-0.029 \\
(0.333)\end{array}$ & $\begin{array}{r}-0.060 \\
(0.368)\end{array}$ & $\begin{array}{r}-0.035 \\
(0.373)\end{array}$ \\
\hline$H I N F L_{i t}$ & $\begin{array}{r}-0.268 \\
(0.394)\end{array}$ & $\begin{array}{r}-0.215 \\
(0.411)\end{array}$ & $\begin{array}{r}-0.334 \\
(0.647)\end{array}$ & $\begin{array}{r}-0.429 \\
(0.634)\end{array}$ \\
\hline FIRSTYEAR & $\begin{array}{r}0.194 \\
(0.231)\end{array}$ & $\begin{array}{r}0.153 \\
(0.230)\end{array}$ & $\begin{array}{r}0.238 \\
(0.273)\end{array}$ & $\begin{array}{r}0.250 \\
(0.271)\end{array}$ \\
\hline$M F_{i t}$ & $\begin{array}{l}0.312 * \\
(0.193)\end{array}$ & $\begin{array}{l}0.400 * * \\
(0.199)\end{array}$ & $\begin{array}{r}0.331 \\
(0.261)\end{array}$ & $\begin{array}{r}0.370 \\
(0.266)\end{array}$ \\
\hline$U S I N T_{t}$ & $\begin{array}{l}-0.067 * \\
(0.039)\end{array}$ & $\begin{array}{l}-0.071 * \\
(0.039)\end{array}$ & $\begin{array}{l}-0.093 * * \\
(0.044)\end{array}$ & $\begin{array}{l}-0.089 * * \\
(0.044)\end{array}$ \\
\hline$L E F T_{i t}$ & $\begin{array}{r}0.251 \\
(0.239)\end{array}$ & $\begin{array}{r}0.149 \\
(0.226)\end{array}$ & $\begin{array}{r}-0.031 \\
(0.350)\end{array}$ & $\begin{array}{r}-0.092 \\
(0.354)\end{array}$ \\
\hline$R I G H T_{i l}$ & $\begin{array}{r}0.187 \\
(0.196)\end{array}$ & $\begin{array}{r}0.183 \\
(0.187)\end{array}$ & $\begin{array}{r}-0.144 \\
(0.333)\end{array}$ & $\begin{array}{r}-0.091 \\
(0.349)\end{array}$ \\
\hline$O P E N_{i t}$ & $\begin{array}{r}-0.001 \\
(0.001)\end{array}$ & $\begin{array}{r}0.000 \\
(0.001)\end{array}$ & $\begin{array}{r}0.007 \\
(0.009)\end{array}$ & $\begin{array}{r}0.010 \\
(0.010)\end{array}$ \\
\hline $\begin{array}{l}\text { Log } \mathrm{L} \\
\text { Wald test of joint significance } \\
\text { ( } p \text {-value) } \\
\text { Number of observations }\end{array}$ & $\begin{array}{r}0.00 \\
805\end{array}$ & $\begin{array}{r}0.00 \\
805\end{array}$ & $\begin{array}{r}0.00 \\
805\end{array}$ & $\begin{array}{l}0.00 \\
805\end{array}$ \\
\hline
\end{tabular}

Note 1: The dependent variable is the change in the Financial Liberalization Index.

Note 2: Robusl standard errors are in parentheses; adjusled for clustering by country. *** denotes significance al the 1 percent level; ${ }^{* *}$ denotes significance at the 5 percent level; * denotes significance at the 10 percent level.

Next, since $\alpha$ measures the degree of status quo bias, an alternative econometric specification is for the shock, idcology and structure variables to enter via their effect on $\alpha$, rather than directly on $\Delta F L_{i t}$. That is,

$$
\Delta F L_{i t}=\alpha\left(F L_{i t}^{*}-F L_{i, t-1}\right)+\varepsilon_{i t}
$$


where

$$
\alpha=\theta_{1} \cdot F L_{i, t-1}+\theta_{2}\left(R E G_{-} F L_{i, t-1}-F L_{i, t-1}\right)+\theta_{3}{ }^{\prime S H O C K S_{i t}}+\theta_{4}{ }^{\prime} I D E O L O G Y_{i t}+\theta_{5}{ }^{\prime} S T R U C T U R E_{i t}
$$

Below we present the case where $F L_{i t}^{*}=c .{ }^{20}$ This implies the following specification:

$$
\begin{aligned}
& \Delta F L_{i t}=\theta_{1} F L_{i, t-1}+\theta_{2} F L_{i, t-1}^{2} \\
& +\theta_{3}\left(R E G_{-} F L_{i, t-1}-F L_{i, t-1}\right)+\theta_{4}\left(R E G_{-} F L_{i, t-1}-F L_{i, t-1}\right) \cdot F L_{i, t-1} \\
& +\theta_{5}{ }^{\prime} \mathrm{SHOCK}_{i t}+\theta_{6}{ }^{\prime} \mathrm{SHOCK}_{i t} \cdot F L_{i, t-1} \\
& +\theta_{7}^{\prime} I D E O L O G Y_{i t}+\theta_{8}^{\prime} I D E O L O G Y_{i t} \cdot F L_{i, t-1} \\
& +\theta_{9}{ }^{\prime S T R U C T U R E} E_{i t}+\theta_{10}{ }^{\prime} S_{T R R U C T U R E} \cdot F L_{i, t-1}+\varepsilon_{i t}
\end{aligned}
$$

We report the results from these estimations in Table 9. The inverse U-shaped relationship between $\triangle F L_{i t}$ and $F L_{i, t-1}$ continues to hold. The interaction between the regional liberalization gap with the level of a country's liberalization is positive and significant, suggesting that regional competitive spirit becomes more pronounced as the level of liberalization increases. The respective positive and negative effects of $B O P_{i t}$ and $B A N K_{i t}$ on $\triangle F L_{i t}$ remain, as before. The dummy for the first year in office is positive and significant at the 10 percent level, and the interaction term is negative and significant at 5 percent. The implication is that first year in office has a positive effect on reforms when the level of liberalization is low but that this effect tapers off as the level of liberalization rises. Similarly, the IMF program dummy is positive and significant at the 5 percent level, but the coefficient on the interaction term $I M F_{i t} \cdot F L_{i, t-1}$ is negative and is also significant at the 5 percent level. This suggests that the earlier ambiguity with respect to the role of IMF programs arose because these programs have the strongest effect on reform likelihood in countries that are still highly repressed, and most in need of reform, but the effect declines thereafter. The additional noteworthy finding is the positive effect of trade openness on the pace of reform at low levels of liberalization. As the negative coefficient on the interaction term indicates, this positive effect falls away as the level of liberalization increases.

${ }^{20}$ The cases where $F L_{i t}^{*}=1$ and $F L_{i t}^{*}=a+b Y_{i t}$, which produce similar results, are available from the authors on request. Since the world interest rate is the same across countries, we do not interact it with $F L_{i, t-1}$, as the interaction term is highly correlated (0.844) with the uninteracted $F L_{i, t-1}$. 
Table 9. Ordered Logit Estimates: Alternative Specifications (Equation 4)

\begin{tabular}{|c|c|c|c|c|}
\hline \multirow[b]{2}{*}{$F L_{i, t-1}$} & \multicolumn{2}{|c|}{ Without Country Fixed Effects } & \multicolumn{2}{|c|}{ With Country Fixed Effects } \\
\hline & 3.824 & $(1.445) * * *$ & 4.486 & $(2.085) * *$ \\
\hline$\left(F L_{i, t-1}\right)^{2}$ & -3.644 & $(1.538)^{* *}$ & -2.930 & $(2.580)$ \\
\hline$R E G_{-} F L_{i, t-1}-F L_{i, t-1}$ & 0.094 & $(0.569)$ & 1.277 & $(1.378)$ \\
\hline$\left(R E G_{-} F L_{i, t-1}-F L_{i, t-1}\right) \times F L_{i, t-1}$ & 3.387 & $(1.852) *$ & 8.918 & $(2.509) * * *$ \\
\hline$B O P_{i}$ & 0.834 & $(0.292) * * *$ & 0.796 & $(0.421)^{*}$ \\
\hline$B O P_{i t} \times F L_{i, t-1}$ & -0.901 & $(0.601)$ & -0.984 & $(0.870)$ \\
\hline$B A N K_{i t}$ & -0.901 & $(0.539) *$ & -1.064 & $(0.590) *$ \\
\hline$B A N K_{i t} \times F L_{i, i-1}$ & -0.079 & $(1.071)$ & -0.006 & $(1.163)$ \\
\hline RECESSION & -0.518 & $(0.461)$ & -0.555 & $(0.546)$ \\
\hline$R_{E C E S S I O N}{ }_{i t} \times F L_{i, t-1}$ & 1.224 & $(0.890)$ & 1.185 & $(0.977)$ \\
\hline$H I N F L_{i t}$ & 0.346 & $(0.496)$ & 0.415 & $(0.778)$ \\
\hline$H I N F L_{i t} \times F L_{i, t-1}$ & -2.535 & $(1.356)^{*}$ & -3.568 & $(1.520) * *$ \\
\hline FIRSTYEAR $_{i}$ & 0.564 & $(0.283)^{* *}$ & 0.607 & $(0.319) *$ \\
\hline$F_{R S T Y E A R_{i t}} \times F L_{i, t-1}$ & -1.140 & $(0.621) *$ & -1.041 & $(0.717)$ \\
\hline$I M F_{i t}$ & 0.752 & $(0.259) * * *$ & 0.692 & $(0.336)^{* *}$ \\
\hline$I M F_{i t} \times F L_{i, t-1}$ & -1.502 & $(0.674)^{* *}$ & -1.762 & $(0.891)^{* *}$ \\
\hline$U S I N T_{t}$ & -0.073 & $(0.041) *$ & -0.088 & $(0.043)^{* *}$ \\
\hline$L E F T_{i t}$ & -0.117 & $(0.391)$ & -0.611 & $(0.530)$ \\
\hline$L E F T_{i t} \times F L_{i, t-1}$ & 0.661 & $(1.009)$ & 1.323 & $(1.208)$ \\
\hline$R / G H T_{i t}$ & 0.366 & $(0.304)$ & 0.151 & $(0.381)$ \\
\hline$R I G H T_{i t} \times F L_{i, t-1}$ & -0.397 & $(0.963)$ & -0.132 & $(1.210)$ \\
\hline$O P E N_{i t}$ & 0.003 & $(0.006)$ & 0.029 & $(0.016)^{*}$ \\
\hline$O P E N_{i t} \times F L_{i, t-l}$ & -0.005 & $(0.006)$ & -0.045 & $(0.018) * *$ \\
\hline $\log L$ & -737.97 & & -718.92 & \\
\hline \multicolumn{5}{|c|}{ Wald test of joint significance ( $p$-value) } \\
\hline & 0.00 & & 0.00 & \\
\hline Number of observations & 805 & & 805 & \\
\hline
\end{tabular}

Note 1: The dependent variable is the change in the Financial Liberalization Index.

Note 2: Robust standard errors are in parentheses; adjusted for clustering by country. *** denotes significance at the I percent level; ${ }^{* *}$ denotes significance at the 5 percent level; * denotes significance at the 10 percent level.

As noted in Greene (2000), there is no widely accepted method for assessing goodness-of-fit in ordered logit models. ${ }^{21}$ In Table 9 we compare the actual policy implemented with the

${ }^{21}$ Commonly reported measures, such as McFadden's pseudo- $\mathrm{R}^{2}$, do not have any interpretation for values between 0 and 1 . 
model's predicted policy, where the predictions are generated using equation (4). To mitigate the effects of the extremely unbalanced data, we have grouped large reversals and reversals together, and reforms and large reforms together, although this still leaves the sample highly unbalanced, with reversals/large reversals comprising only 4 percent of observations. Only 7 percent ( 2 of the 27) of reversals are correctly predicted, but the two reversals that the model correctly predicts are the most significant reversals in our sample-Argentina in 1982 and Venezuela in 1994. The model does a much better job of predicting status quo observations (65 percent) and reform/large reform episodes ( 59 percent). Overall, the model correctly predicts 62 percent of observations.

Table 10. Goodness of Fit: Actual versus Predicted Policy

\begin{tabular}{lcccc}
\hline & \multicolumn{4}{c}{ Predicted Policy } \\
\cline { 2 - 5 } Actual Policy & $\begin{array}{c}\text { Reversal/ } \\
\text { Large Reversal }\end{array}$ & Status Quo & $\begin{array}{c}\text { Reform/ } \\
\text { Large Reform }\end{array}$ & Total \\
\hline Reversal/Large Reversal & 2 & 20 & 5 & 27 \\
Status quo & $(.07)$ & 442 & 155 & 613 \\
Reform/Large Reform & 16 & $(.72)$ & 102 & 165 \\
& 1 & 62 & $(.62)$ & 805 \\
\hline Total & 19 & 524 & 262 & $(.68)$ \\
\hline
\end{tabular}

Note: Numbers in parentheses are the percentage of correctly predicted observations. For example, 59 percent ( 97 out of 165) of reform/large reform episodes are correctly predicted. Overall, $(2+442+102)$ out of 805 or 68 percent of all observations are correctly predicted.

\section{Further Sensitivity Analysis}

We tested for the robustness of the regional diffusion effect by including regional dummies. The omitted "regional" dummy was the one corresponding to OECD member countries. The coefficients on the regional dummies are mostly insignificant, and our previous results are all robust to their inclusion. ${ }^{22}$ Our results are also unchanged when we drop the four OECD countries that were already highly liberalized at the start of the sample period-Canada, Germany, the United Kingdom, and the United States.

${ }^{22}$ The estimation results described in this section are not shown but are available from the authors upon request. 
A second fixed factor that we control for is legal origin. La Porta and others (1997) find that legal origin is a significant predictor of one measure of financial development, the ratio of externally held equity market capitalization to GNP (see also Levine, Loayza, and Beck (2000) for similar findings). Although these studies were cross-sectional, and the legal origin variable may be a less powerful predictor in our panel setting, we include it in the regressions. We find that our previous results are robust to the inclusion of these dummies, and that the legal origin variables are not significant.

Also, we found no significant differences between presidential and parliamentary systems in terms of the frequency and timing of reform. The coefficient on the presidential system dummy is negative, suggesting a lower propensity to reform relative to parliamentary systems, but the effect is not significant. Interactions between the system of government and other variables, such as balance of payments and banking crisis dummies, were also explored but no significant effects were found. Again, our results are robust to the inclusion of these variables.

Finally, we explored timing differences in the changes to the six components of our aggregate financial reform index. A few findings are of interest. Credit controls tend to be introduced in periods of high inflation. IMF programs are especially associated with the lifting of interest rate controls. Entry barriers are likely to be lifted in the first year of a new government and also in recessionary periods. Trade openness is associated with a greater tendency to privatize banks. And, somewhat interestingly, capital account liberalization is more likely under left-wing governments. Thus, the different aspects of the multifaceted reform process are apparently triggered by differing influences. Our results suggest that these changes lay the basis for further change.

\section{Conclusions}

In this paper we undertook an extensive statistical analysis of the determinants of financial reform, using a newly constructed cross-country database of financial liberalization covering 35 countries over the period 1973-96. Liberalization occurred as a combination of discrete changes and gradual "learning." Since the episodic changes in responses to shocks were not unidirectional, domestic learning - initial reforms raising the likelihood of further reformsand external learning through observing regional leaders were essential to the dynamic that sustained widespread reform. We reach five specific conclusions.

First, countries whose financial sectors were fully repressed were the ones with the strongest tendency to maintain their policy stance and hence stay fully repressed. However, where initial reforms occurred, and the financial sector became even only partially repressed, the likelihood of further reforms increased substantially. The self-sustaining nature of reforms can be explained in several ways. Initial reforms tended to strengthen those who benefited from (and lobbied for) reforms relative to those who opposed them. It may also have been that reforms caused changes that made further reforms necessary. An interesting example is the Japanese financial liberalization experience, which received its initial impetus from the emergence of large fiscal deficits in the 1970 s and the need to finance them. The resultant 
development of the government bond market created demand for reduced restrictions on the corporate bond market. In turn, the development of the corporate bond market resulted in a substantial revenue decline for commercial banks prevented from participating in the bond market. This led the government to liberalize the scope of banks' activities. Thus, the liberalization process was one of reforms begetting new ones.

Second, regional diffusion effects appear to have been important: a country was under greater pressure to liberalize the further its state of liberalization was from the region's leader. Our results suggest that this reflected, in part, that countries within a region possess similar characteristics and were likely to be motivated by similar objectives, including competition for the same pool of international capital. This competitive effect became stronger as the levels of liberalization increased.

Third, among shocks, the status quo was likely to be altered-through both reforms and reversals - in the first year of a new government, with reforms more likely when the liberalization level was also low. A decline in U.S. interest rates accelerated reforms, and a rise in rates set them back. IMF program conditionality appears to have had a strong influence under conditions of relatively high repression and a declining effect, thereafter.

Fourth, crises did trigger action, and made maintaining the status quo less likely. There apparently was a need to do something, anything, when things got bad. However, actions were not unidirectional, and different types of crisis had different effects. Balance of payments crises raised reform likelihood. However, banking crises had the opposite effect. Both of these findings are robust. Reversals following banking crises arose, in part, from the nationalizations of banks. Since banking crises are merely manifestations of extreme banking sector fragility, it is not surprising that reforms were not pushed further during such periods since, in the short run, they risked further weakening franchise values of incumbent banks. Instead, governments attempting to resolve banking crises through takeovers of weak banks by stronger ones were apt to offer incentives, such as temporary monopoly power.

Finally, among variables representing ideology and structure, only trade openness appeared related to the pace of reform. There was no evidence that right-wing governments were more reform-oriented than left-wing governments. If anything, the propensity of left-wing governments to reform was slightly higher than for right-wing governments, although the difference was not statistically significant. Unchanging features such as the form of government and legal systems were also not influential. Trade openness did appear to hasten reform at low levels of liberalization.

For policymakers, our results suggest that even small reforms are potentially a large victory, since the reform process tends to build its own momentum. Reforms need not be all-ornothing, and if political conditions are such that large reforms are not feasible, it may be worth implementing the feasible reforms. Also, policy reform becomes more likely under certain conditions. Governments have used balance of payments crises, in particular, to push through reforms. The "honeymoon period," an incumbent's first year in office, may also be a 
period when policy reform is possible. However, in such fluid situations - especially during banking crises-policymakers also need to guard against backsliding.

This paper, though focused on the financial sector, offers pointers for the broader literature on the political economy of reform. Our results reinforce some widely held conclusions, but also confirm that the ambiguities in the case study literature are real, since events that alter the status quo may lead to both reforms and reversals. The analysis suggests that further insights into the reform process will be achieved by considering particular reform areas, rather than by focusing on broad reform episodes. In turn, this requires investment in the calibration of reform efforts across countries and careful specification of the determinants of reforms. Empirical analysis must also allow for a dynamic specification of the reform process. A rich set of hypotheses linking reforms, their determinants, and economic performance awaits further exploration. 


\section{Data Description}

The dependent variable in the paper is derived from the financial liberalization database, and was described in detail in the paper. Below we describe the sources used for and the transformations of the independent variables.

The crisis variables are defined as follows. The balance of payments crisis variable ( $\left.B O P_{i t}\right)$ and the banking crisis variable ( $B A N K_{i t}$ ) are based on the crises identified in Bordo and others (2001). As described in that paper (p. 4), a balance of payments crisis is identified by "a forced change in parity, abandonment of a pegged exchange rate, or an international rescue," or if an index of exchange market pressure (a weighted average of exchange rate, reserve, and interest rate changes) exceeds a critical threshold of one and a half standard deviations above its mean. Banking crises are identified by periods of "financial distress resulting in the erosion of most or all of aggregate banking system capital." Because both types of crisis can be protracted, the dummy variables $B O P_{i t}$ and $B A N K_{i t}$ are set equal to 1 if a balance of payments or banking crisis, respectively, has occurred within the past two years. Finally, the recession dummy variable RECESSION ${ }_{i t}$ is defined as a year where annual real GDP growth is negative, and the high inflation dummy $H I N F L_{i t}$ is defined as a year in which annual inflation exceeds 50 percent. Both are based on data from the IMF's International Financial Statistics database.

The political variables were defined as follows. The drastic political change variable $D P C_{i t}$ was derived using the Polity IV dataset of Marshall and Jaggers (2000). The Polity IV dataset contains a variable called polity, which refers to the difference between the democracy and autocracy indices for a country. Following Tornell (1998), drastic political change is defined as a change of three or more in the polity of a country. The drastic political change measure is meant to capture periods such as coups d'etat, the imposition or lifting of martial law, or other substantial changes in the form of government. The first year in office dummy FIRSTYEAR it is based on the YRSOFFC variable in the World Bank's (2001) Database of Political Institutions. The political orientation variables, $L E F T_{i t}$, RIGHT it and $C E N T E R_{i t}$, were taken from the same database. The ideology measure in the World Bank's Database of Political Institutions designates party orientation based on the presence of certain terms in the party name or description. Those named or described as "conservative", "Christian Democratic" or "right-wing" are classified in one group, those described as "centrist" are a second group, and those named or described as "communist", "socialist", "Social Democratic" or "left-wing" are a third group. Those that cannot be classified into these three categories are listed as "Other".

The IMF program dummy variable, $I M F_{i t}$, was constructed using the program dates from the History of Lending Arrangements reported by the IMF's Treasurer's Department and available through the IMF's external website (www.imf.org). Finally, to measure the level of economic development $Y_{i t}$ we use GDP per capita in PPP terms from the Penn World Tables. 
Table A. 1. The Finaticial Liberalization Index for 36 Lcononies, 1973-96

$(0=$ Full Repression; $18=$ =Full I ibcralization $)$

\begin{tabular}{|c|c|c|c|c|c|c|c|c|c|c|c|c|}
\hline & \multirow[b]{2}{*}{ Indonesia } & \multirow[b]{2}{*}{ Korca } & \multirow[b]{2}{*}{ Malaysia } & \multirow[b]{2}{*}{ Philippines } & \multirow[b]{2}{*}{ Singapore } & \multirow[b]{2}{*}{ Taiwan } & \multirow[b]{2}{*}{ Thailand } & \multicolumn{5}{|c|}{ South $\Lambda$ sia } \\
\hline & & & & & & & & Bangladesh & India & Nepal & Pakistan & Sri Lanka \\
\hline 1973 & 1 & 0 & 7 & 3 & 15 & 0 & 2 & 0 & 0 & 1 & 2 & 0 \\
\hline 1975 & 1 & 0 & 5 & 3 & 15 & 0 & 2 & 0 & 0 & 0 & 0 & 0 \\
\hline 1976 & 1 & 0 & 6 & 3 & 15 & 0 & 2 & 0 & 0 & 0 & 0 & 0 \\
\hline 1977 & 1 & 0 & 6 & 3 & 15 & 0 & 2 & 0 & 0 & 0 & 0 & 1 \\
\hline 1978 & 1 & 0 & 9 & 3 & 16 & 0 & 2 & 0 & 0 & 0 & 0 & 6 \\
\hline 1980 & 1 & 0 & 10 & 6 & 16 & 0 & 5 & 0 & 0 & ) & 0 & 7 \\
\hline 1981 & 1 & 3 & 10 & 6 & 16 & 0 & 5 & 0 & 0 & 0 & 0 & 7 \\
\hline 1982 & 1 & 6 & 10 & 6 & 16 & 0 & 5 & 2 & 0 & 0 & 0 & 7 \\
\hline 1983 & 4 & 6 & 10 & 8 & 16 & 0 & 5 & 2 & 0 & 1 & 0 & 7 \\
\hline 1984 & 4 & 7 & 10 & 8 & 16 & 0 & 5 & 2 & 0 & 1 & 0 & 7 \\
\hline 1985 & 4 & 8 & 9 & 8 & 16 & 0 & 5 & 2 & 0 & 1 & 0 & 7 \\
\hline 1986 & 4 & 9 & 9 & 8 & 16 & 0 & 5 & 2 & 0 & 2 & 0 & 7 \\
\hline 1987 & 4 & 9 & 12 & 8 & 16 & 1 & 5 & 2 & 0 & 2 & 0 & 7 \\
\hline 1988 & 8 & 9 & 12 & 8 & 16 & 1 & 5 & 2 & 0 & 2 & 0 & 8 \\
\hline 1990 & 8 & 8 & 13 & 9 & 16 & 4 & 10 & 4 & 0 & 4 & I & 7 \\
\hline 1991 & 9 & 10 & 13 & 9 & 16 & 4 & 10 & 6 & 1 & 4 & 4 & 7 \\
\hline 1992 & 10 & 10 & 13 & 10 & 16 & 6 & 12 & 7 & 4 & 4 & 5 & 7 \\
\hline 1993 & 10 & 10 & 13 & 10 & 16 & 6 & 13 & 7 & 6 & 4 & 5 & 8 \\
\hline 1994 & 10 & 10 & 12 & 10 & 16 & 6 & 13 & 8 & 6 & 6 & 8 & 9 \\
\hline 1995 & 10 & 10 & 12 & 11 & 16 & 6 & 13 & 7 & 6 & 6 & 10 & 9 \\
\hline 1996 & 11 & 10 & 12 & 11 & 16 & 6 & 13 & 7 & 6 & 6 & 10 & 9 \\
\hline
\end{tabular}


Table A.1. (continued)

\begin{tabular}{|c|c|c|c|c|c|c|c|c|c|c|c|c|c|}
\hline & \multicolumn{7}{|c|}{ Latin America } & \multicolumn{6}{|c|}{ Africa and the Middle East } \\
\hline & Argentina & Brazil & Chile & Colombia & Mexico & Рел & Venezuela & Egypt & Ghana & Isracl & Morocco & South Africa & Zimbabwe \\
\hline 1973 & 0 & 1 & 0 & 3 & 3 & 0 & 2 & 1 & 0 & 5 & 1 & 7 & 2 \\
\hline 1974 & 0 & 1 & 8 & 4 & 4 & 0 & 2 & 1 & 0 & 5 & 1 & 7 & 2 \\
\hline 1975 & 0 & 1 & 9 & 3 & 4 & 0 & 2 & 1 & 0 & 5 & 1 & 7 & 2 \\
\hline 1976 & 0 & 3 & 11 & 3 & 4 & 0 & 2 & 1 & 0 & 5 & 1 & 5 & 2 \\
\hline 1977 & 11 & 3 & 11 & 3 & 4 & 0 & 2 & 1 & 0 & 7 & 1 & 5 & 2 \\
\hline 1978 & 11 & 3 & 12 & 3 & 4 & 0 & 2 & 1 & 0 & 7 & 1 & 5 & 2 \\
\hline 1979 & 11 & 1 & 14 & 3 & 4 & 0 & 2 & 1 & 0 & 5 & 1 & 5 & 2 \\
\hline 1980 & 11 & 1 & 14 & 4 & 4 & 0 & 2 & 1 & 0 & 5 & 1 & 11 & 2 \\
\hline 1981 & 11 & 2 & 14 & 4 & 4 & 0 & 2 & 1 & 0 & 5 & 1 & 11 & 2 \\
\hline 1982 & 3 & 2 & 13 & 3 & 2 & 0 & 2 & 1 & 0 & 5 & 1 & 11 & 2 \\
\hline 1983 & 3 & 2 & 12 & 3 & 2 & 0 & 2 & 1 & 0 & 3 & 1 & 13 & 2 \\
\hline 1984 & 3 & 2 & 13 & 3 & 2 & 0 & 2 & 1 & 0 & 3 & 1 & 1.3 & 2 \\
\hline 1985 & 3 & 2 & 15 & 3 & 2 & 0 & 2 & 1 & 0 & 3 & 1 & 12 & 2 \\
\hline 1986 & 3 & 2 & 15 & 3 & 2 & 0 & 2 & 1 & 0 & 3 & 1 & 12 & 2 \\
\hline 1987 & 5 & 2 & 15 & 3 & 2 & 0 & 2 & 1 & 2 & 10 & 1 & 12 & 2 \\
\hline 1988 & 6 & 4 & 15 & 3 & 3 & 0 & 2 & 1 & 3 & 10 & 1 & 12 & 2 \\
\hline 1989 & 6 & 5 & 15 & 3 & 9 & 0 & 4 & 1 & 4 & 10 & 2 & 12 & 2 \\
\hline 1990 & 6 & 5 & 15 & 4 & 9 & 0 & 4 & 1 & 4 & 11 & 2 & 13 & 5 \\
\hline 1991 & 6 & 6 & 15 & 10 & 12 & 5 & 8 & 9 & 5 & 11 & 3 & 14 & 5 \\
\hline 1992 & 12 & 6 & 15 & 10 & 12 & 11 & 8 & 9 & 5 & 11 & 3 & 14 & 5 \\
\hline 1993 & 12 & 6 & 15 & 9 & 12 & 13 & 8 & 9 & 6 & 12 & 7 & 14 & 6 \\
\hline 1994 & 12 & 6 & 15 & 9 & 12 & 13 & 3 & 9 & 7 & 12 & 8 & 14 & 8 \\
\hline 1995 & 12 & 7 & 15 & 9 & 12 & 13 & 3 & 9 & 8 & 12 & 8 & 17 & 8 \\
\hline 1996 & 12 & 8 & 15 & 9 & 13 & 13 & 8 & 10 & 8 & 12 & 11 & 17 & 8 \\
\hline
\end{tabular}


Table A.1. (continued)

\begin{tabular}{|c|c|c|c|c|c|c|c|c|c|c|}
\hline & \multicolumn{10}{|c|}{ OECD Countries } \\
\hline & Australia & Canada & France & Jnited Kingdon & Germany & Italy & Japan & New Zcaland & Turkey & United States \\
\hline 1973 & 0 & 15 & 5 & 12 & 16 & 5 & 4 & 2 & 1 & 13 \\
\hline 1974 & 0 & 15 & 5 & 12 & 16 & 5 & 4 & 2 & 1 & 14 \\
\hline 1975 & 0 & 15 & 5 & 12 & 16 & 6 & 4 & 2 & 1 & 14 \\
\hline 1976 & 0 & 15 & 5 & 12 & 16 & 6 & 4 & 4 & 1 & 14 \\
\hline 1977 & 0 & 15 & 5 & 12 & 16 & 6 & 4 & 4 & 1 & 14 \\
\hline 1978 & 0 & 15 & 5 & 12 & 16 & 6 & 4 & 4 & 1 & 14 \\
\hline 1979 & 0 & 15 & 5 & 14 & 16 & 6 & 6 & 4 & 1 & 14 \\
\hline 1980 & 0 & 16 & 5 & 15 & 16 & 6 & 7 & 4 & 6 & 15 \\
\hline 1981 & 1 & 16 & 5 & 17 & 16 & 6 & 7 & 2 & 6 & 15 \\
\hline 1982 & 3 & 16 & 4 & 17 & 16 & 6 & 7 & 2 & 6 & 16 \\
\hline 1983 & 3 & 16 & 4 & 17 & 16 & 8 & 7 & 2 & 5 & 16 \\
\hline 1984 & 6 & 16 & 7 & 17 & 16 & 8 & 9 & 10 & 5 & 16 \\
\hline 1985 & 9 & 16 & 9 & 17 & 16 & 8 & 10 & 13 & 5 & 16 \\
\hline 1986 & 9 & 16 & 12 & 18 & 16 & 6 & 10 & 14 & 7 & 16 \\
\hline 1987 & 11 & 16 & 13 & 18 & 16 & 6 & 10 & 15 & 8 & 16 \\
\hline 1988 & 13 & 16 & 13 & 18 & 16 & 8 & 10 & 15 & 9 & 16 \\
\hline 1989 & 13 & 16 & 13 & 18 & 16 & 9 & 10 & 16 & 13 & 16 \\
\hline 1990 & 13 & 16 & 13 & 18 & 16 & 12 & 10 & 16 & 12 & 16 \\
\hline 1991 & 13 & 17 & 13 & 18 & 16 & 12 & 11 & 16 & 12 & 16 \\
\hline 19.92 & 14 & 18 & 13 & 18 & 16 & 13 & 11 & 18 & 12 & 16 \\
\hline 1993 & 14 & 18 & 14 & 18 & 17 & 15 & 13 & 18 & 12 & 16 \\
\hline 1994 & 17 & 18 & 14 & 18 & 17 & 15 & 13 & 18 & 12 & 17 \\
\hline 1995 & 17 & 18 & 14 & 18 & 17 & 15 & 14 & 18 & 12 & 17 \\
\hline 1996 & 17 & 18 & 14 & 18 & 17 & 15 & 14 & 18 & 12 & 17 \\
\hline
\end{tabular}




\section{REFERENCES}

Alesina, Alberto, and Nouriel Roubini, 1992, "Political Cycles in OECD Economies," Review of Economic Studies Vol. 59, No. 4, pp. 663-88.

Axelrod, Robert, 1997, "The Dissemination of Culture: A Model with Local Convergence and Global Polarization," Journal of Conflict Resolution Vol. 41, pp. 203-26.

Bartolini, Leonardo, and Allan Drazen, "When Liberal Policies Reflect External Shocks, What Do We Learn?" Journal of International Economics Vol. 42, pp. 249-73.

Bates, Robert H., and Anne O. Krueger, eds., 1993, Political and Economic Interactions in Economic Policy Reform: Evidence from Eight Countries (Oxford, England; Cambridge, Massachusetts: Blackwell).

Bekaert, Geert, and Campbell R. Harvey, 2000, "Foreign Speculators and Emerging Equity Markets," Journal of Finance Vol. 55, pp. 565-614.

Bordo, Michael D., Barry Eichengreen, Daniela Klingebiel, and Maria Soledad Martinez Peria, 2001, "Financial Crises: Lessons from the Last 120 Years," Economic Policy: A European Forum No. 32 (April), pp. 51-82.

Brinks, Daniel, and Michael Coppedge, 2001, "Patterns of Diffusion in the Third Wave of Democracy," paper presented at the Annual Meeting of the American Political Science Association.

Bruno, Michael, and William Easterly, 1996, "Inflation's Children: Tales of Crises that Beget Reforms," American Economic Review, Papers and Proceedings, Vol. 86 (May), pp. 213-17.

Caprio, Gerard, Patrick Honohan, and Joseph E. Stiglitz, eds., 2001, Financial Liberalization: How Far, How Fast? (New York: Cambridge University Press).

Cukierman, Alex, and Mariano Tommasi, 1998, "Credibility of Policymakers and of Economic Reforms," in The Political Economy of Reform, ed. by F. Sturzenegger and M. Tommasi (Cambridge, Massachusetts: MIT Press).

De Brouwer, Gordon, and Wisarn Pupphavesa, 1999, Asia Pacific Financial Deregulation (London; New York: Routledge).

Demirguc-Kunt, Asli and Enrica Detragiache, 2001, "Financial Liberalization and Financial Fragility," in Financial Liberalization: How Far, How Fast? ed. by Gerard Caprio, Patrick Honohan and Joseph E. Stiglitz (New York: Cambridge University Press). 
Drazen, Allan, 2000, Political Economy in Macroeconomics, (New Jersey: Princeton University Press).

__- and William Easterly, 2001"Do Crises Induce Reform?: Simple Empirical Tests of Conventional Wisdom," Economics and Politics, Vol. 13(2), pp. 129-157.

Edwards, Sebastian, and Roberto Steiner, 2000, "On the Crisis Hypothesis of Economic Reform: Colombia 1989-1991," Cuadernos de Economia, Vol. 37, No. 112 (December).

Erbas, S. Nuri, 2002, "Primer on Reforms in a Second-Best Ambiguous Environment: A Case for Gradualism." IMF Working Paper 02/50 (Washington: International Monetary Fund).

Fanelli, José Maria, and Rohinton Medhora, eds., 1998, Financial Reform in Developing Countries, (Houndmills, England: IDRC Books and Macmillan Press, Ltd).

Fernandez, Raquel, and Dani Rodrik, 1991, "Resistance to Reform: Status Quo Bias in the Presence of Individual-specific Uncertainty," American Economic Review, Vol. 81, December, pp. 1146-55.

Greene, William H., 2000, Econometric Analysis (Upper Saddle River, New Jersey: PrenticeHall).

Haggard, Stephan, and Steven Webb, 1993, "What Do We Know About the Political Economy of Policy Reform?" World Bank Research Observer 8(2), pp. 143-68.

— 1994, "Introduction," in Voting for Reform: Democracy, Political Liberalization, and Economic Adjustment, ed. by Stephan Haggard and Steven Webb (New York: Oxford University Press).

Harberger, Arnold, 1993, "The Secrets of Success: A Handful of Heroes," American Economic Review, Papers and Proceedings, Vol. 83 (May), pp. 343-50.

Johnston, R. Barry, and V. Sundararajan, eds., 1999, Sequencing Financial Sector Reforms: Country Experiences and Issues (Washington: International Monetary Fund).

Kaminsky, Graciela L., and Carmen M. Reinhart, 1999, "The Twin Crises: The Causes of Banking and Balance-of-Payments Problems," American Economic Review, Vol. 89 (June), pp. 473-500.

Krueger, Anne O., 1993, Political Economy of Policy Reform in Developing Countries (Cambridge, Massachusetts: MIT Press). 
— , 1997, "Trade Policy and Economic Development: How We Learn," The Amercian Economic Review, Vol. 87, Issue 1, pp.1-22.

La Porta, Rafael, Florencia Lopez-de-Silanes, Andrei Shleifer, and Robert Vishny, 1997, "Legal Determinants of External Finance," Journal of Finance, Vol. 52, pp. 1131-49.

Labán, R., and F. Sturzenegger, 1994a, "Distributional Conflict, Financial Adaptation, and Delayed Stabilization," Economics and Politics, Vol. 6, pp. 257-76.

— $1994 b$, "Fiscal Conservatism as a Response to the Debt Crisis," Journal of Development Economics, Vol. 45, pp. 305-24.

Levine, Ross, 1997, "Financial Development and Economic Growth: Views and Agenda," Journal of Economic Literature, June.

Levine, Ross, Normal Loayza, and Thorsten Beck, 2000, "Financial Intermediation and Growth: Causality and Causes," Journal of Monetary Economics, Vol. 46, pp. 31-77.

Lora, Eduardo, 1998, "What Makes Reforms Likely? Timing and Sequencing of Structural Reforms in Latin America," Inter-American Development Bank Working Paper 424.

Marshall, Monty, and Keith Jaggers, 2000, Polity IV Project: Political Regime Characteristics and Transitions, 1800-2000. The dataset is available at http://www.cidcm.umd.edu/inscr/polity/.

Nelson, Joan, 1990, Economic Crisis and Policy Choice: The Politics of Adjustment in the Third World (Princeton, New Jersey: Princeton University Press).

O'Loughlin, John and others, 1998, "The Diffusion of Democracy, 1946-1994," Annals of Association of American Geographers, Vol. 84, No. 4, pp. 545-74.

Persson, Torsten, 2002, "Do Political Institutions Shape Economic Policy?" Econometrica, Vol. 70, No. 3, pp. 883-905.

Przeworski, Adam, 1991, Democracy and the Market: Political and Economic Reforms in Eastern Europe and Latin America (Cambridge, New York: Cambridge University Press).

Quinn, Dennis, 2000, "Democracy and International Financial Liberalization," Georgetown University, http://msb.georgetown.edu/faculty/quinnd/papers/demfin.PDF. 
Rajan, Raghuram, and Luigi Zingales, 2002, "The Great Reversals: The Politics of Financial Development in the 20th Century," forthcoming Journal of Financial Economics, earlier version NBER Working Paper Series (U.S.), No. 8178 (March, 2001), pp. 1-72.

Rogoff, Kenneth, 1990, "Equilibrium Political Budget Cycles," American Economic Review, Vol. 80, pp. 21-36.

Simmons, Beth, and Zachar Elkins, 2001, "The Globalization of Liberalization: Policy Diffusion in the International Political Economy," University of California, Berkeley.

Teichman, Judith, 1997, "Mexico and Argentina: Economic Reform and Technocratic Decision Making," Studies in Comparative International Development, Vol. 32 (1), pp. 31-55.

Tornell, Aaron, 1998, "Reform from Within," NBER Working Paper 6497 (Cambridge, Massachusetts: National Bureau of Economic Research).

Williamson, John, ed., 1994, The Political Economy of Policy Reform (Washington: Institute for International Economics).

— , and Molly Mahar, 1998, "A Survey of Financial Liberalization,” Essays in International Finance, International Finance Section, Department of Economics, Princeton University.

World Bank, 2001, Database of Political Institutions. Available at http://www.worldbank.org/research/growth/political datal.htm, version 3.0 (May). 